SH 463

.573 
2

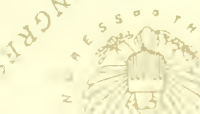

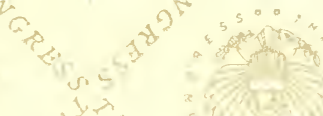

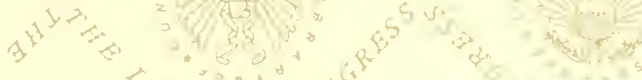

$2 x^{2}$

"स 3

की

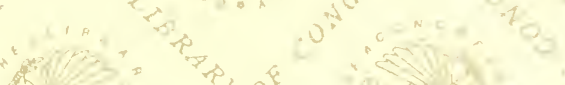

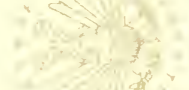

$y^{2}+2$

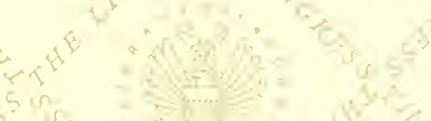

दोiी

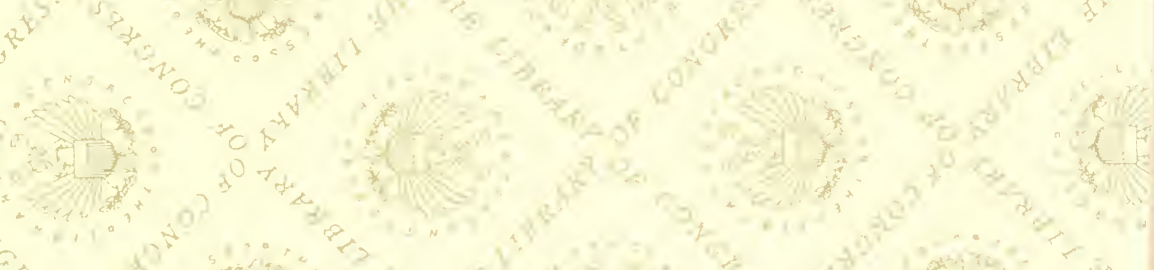

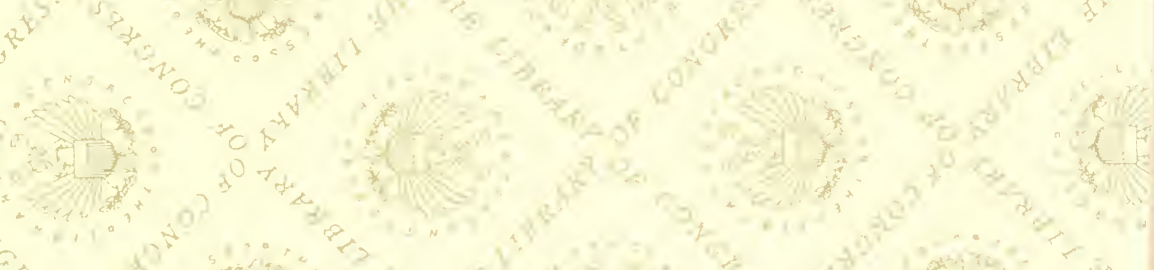

$\rightarrow \sin ^{2}+2+3$

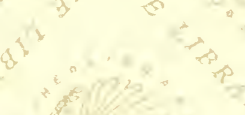

Be 0 ?

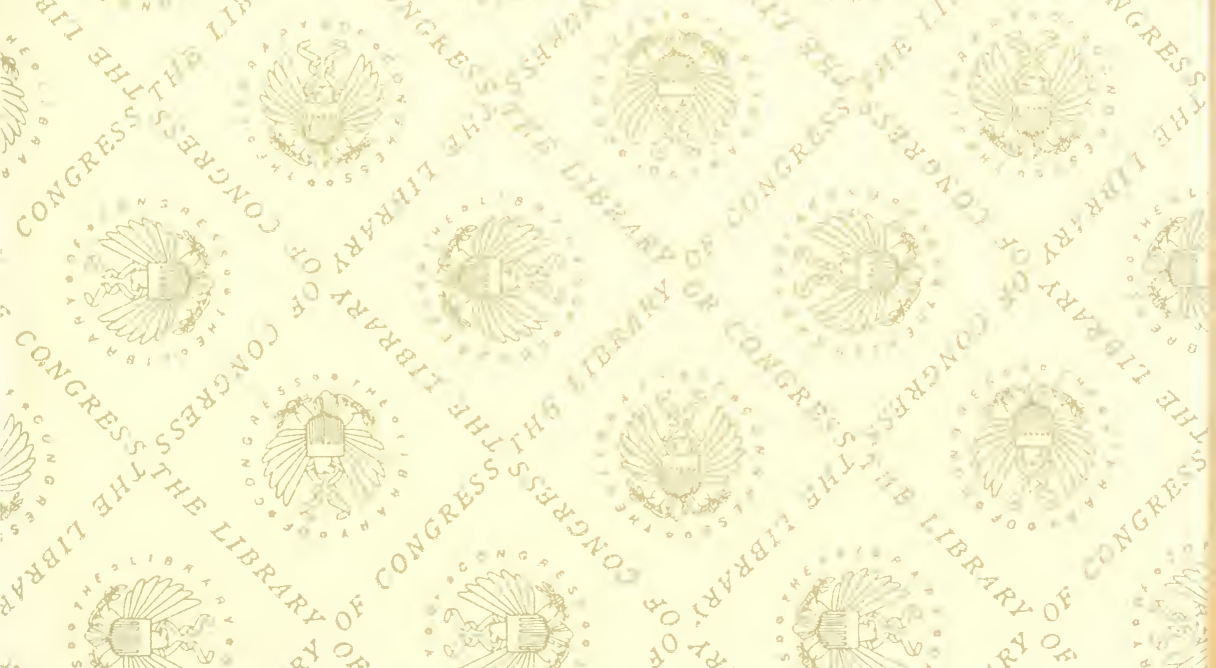

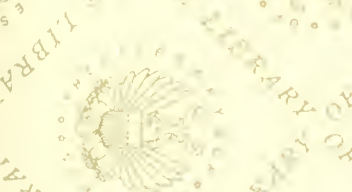

(5)
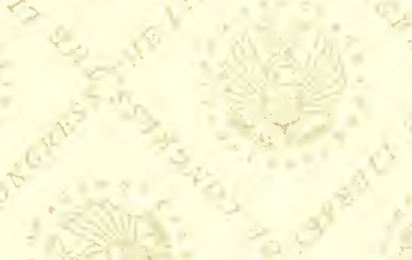



F $2 x^{2}$ 


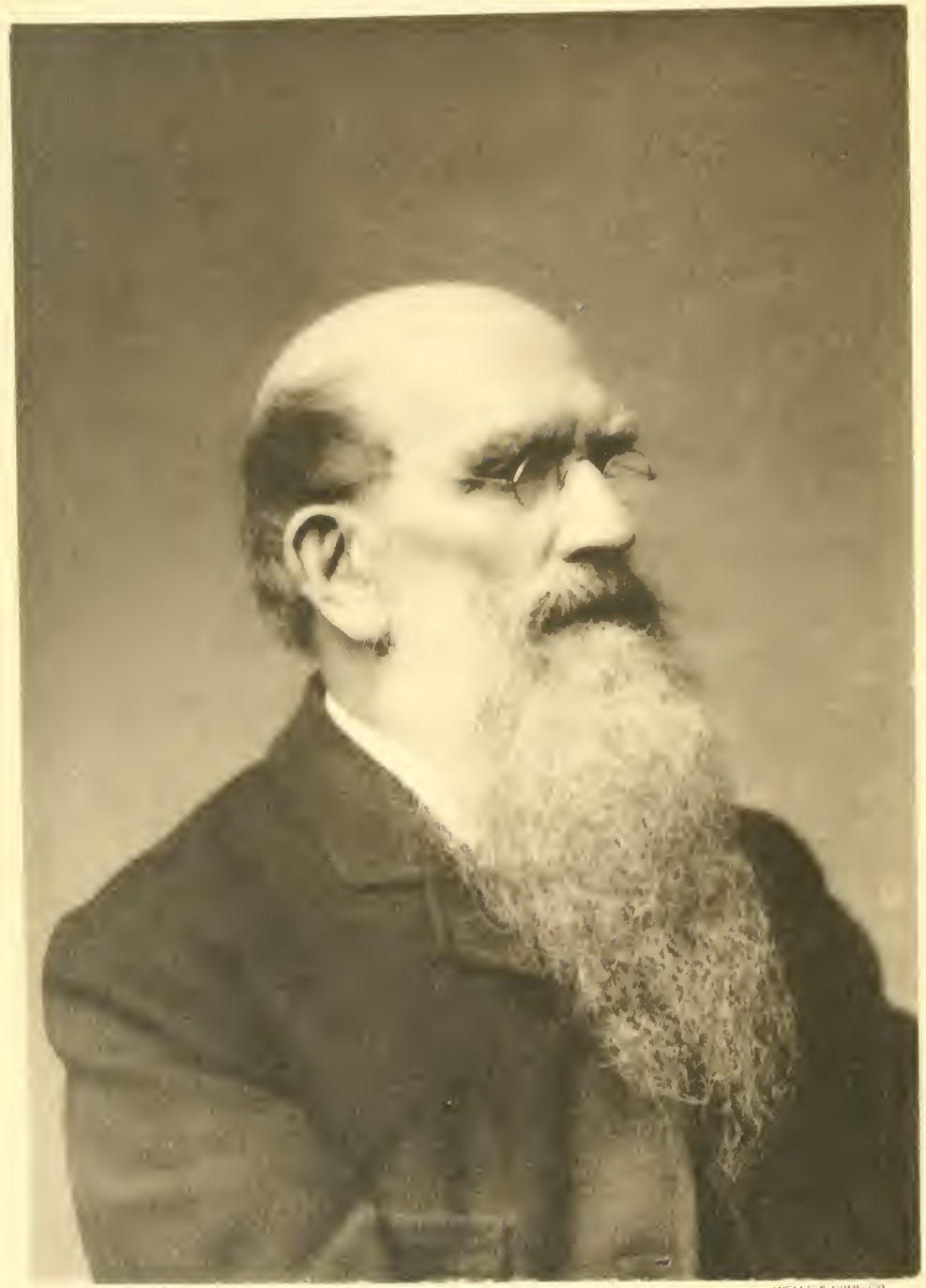

PHOTO-COLLOTYYE

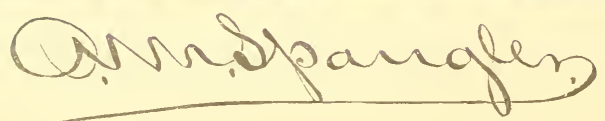




\section{"NEAR BY"}

\section{9}

\section{Fresh and Salt Water Fishing,}

OR

Angling Within a Radius of One Hundred

Miles of Philadelphia.

WHERE TO GO; WHEN TO GO; HOW TO GO.

BY

A. M. SPANGLER,

President of the Anglers' Association of Eastern Pennsylvania.

WITH NUMEROUS ILLUSTRATIONS.

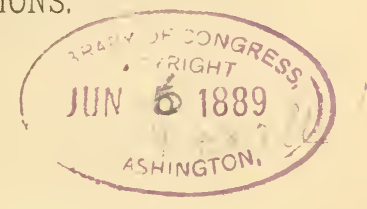

PHILADELPHIA.

1889. 


$$
\begin{aligned}
& 5+4683 \\
& S 7^{2}
\end{aligned}
$$




\section{TO THE READER.}

The love of fishing is innate, and may he said to be almost universal. There are very few memories connected with our earlier experiences, that are recalled with more real pleasure than those referring to the days when, as boys, we went a-fishing. Such recollections afford the keenest enjoyment, when others, relating to incidents which, at the time of their happening, seemed far more worthy of being treasured up in our mental storehouses, are forgotten or dimly remembered. Such pleasant reminiscences have been the inspiration of these pages, and they are given to the world with the sincere hope that any who may chance to peruse them will derive as much satisfaction from their perusal as the author has had in their preparation.

That fishing is indulged to a much greater extent to-day than erer before, will not be questioned. There is a fascination about it that is almost irresistible, which, when coupled with the facts that the facilities for reaching localities where lure-taking fishes are to be found have been much increased, and the devices by which they can be tempted and taken, multiplied and made so much more effective than formerly, readily explains the growing popularity of angling. That there is need for this increasing indulgence in an innocent, alluring and healthful recreation is clearly obrious. We are a busy, go-ahead people, ever eager in the pursuit of wealth or fame, and, consequently, mumindful, in a large degree, of the many sources of enjoyment rouchsafed us by a kind providence. We are too apt, in the unremitting ardor with which we pursue our various callings, to overlook or forget such blessings, excusing our folly and forgetfulness, and placating our consciences with the self-promise, that, when fortune or fame, or both shall have been won, the drudgery of the past will be laid aside, and the remainder of our lives deroted to rational, healthgiving and joy-promoting pursuits.

The change from lifelong pursuits to those of inactivity, brings with it not simply enmui, but worse, pains and penalties that might have been aroided had an occasional day's fishing or some other outing that would have brought these toilers in direct contact with nature in the roods and by the streams, been indulged.

Somebody once wisely said to somebody else, "All work and no play makes Jack a dull boy." Nature has her rerenges as well as her rewards. Don't forget that. She will not permit infringements of her laws without imposing penalties. She may prove lenient, and deal gently with you, but the chances are, she will demand and exact the full penalty of her bond from you. Believe that 
this world of ours is full of enjoyment, if you will but avail yourself of it, and that it will revolve, whether your shoulder is under it or not. Do not wait until age, with its infirmities has come upon you, to lay aside your labors. What shall it profit you, if you gain the wealth of the world after having toiled like a galley-slave for it, and then find yourself a physical wreck, without either capacity or inclination for the enjoyment you hal been looking for throngh all those long wearying years.

There are thonsands of persons, who, having only an occasional holiday, would gladly indulge in a day's outing with rod and reel accompaniment, if they but knew where to go, when to go and how to go where there would be a reasonable probability of finding fish. A Directory for "Near-hy" Fishing, by which is meant, angling within a radins of an hundred miles of Philadelphia, has been a long acknowledged want, and it was with a riew to meeting that want, this little volume was written, with the hope that the information it contains wonld benefit somebody.

It is not claimed for its contents that they are in any sense technical or scientific, or that they describe only game fishes and their whereabouts, for such is not the fact; though it does embrace all the fishes of that class in "near-by" territory.

While the skilled, scientific angler, may possibly find in it something to interest him, the information songht to be imparted is intended for the benefit of the many, whose knowledge of the snlyjects treated is limited, and who are at a loss to know where to apply for such advice as they desire and need. What they w.unt to know is, something about the hahits and qualities of "near-by" fresh and salt water fishes, where they are usually found, when they can lawfully be taken, how to reach their haunts and the kind of tackle and hait requisite to tempt and (apture them. That is all there is of it, and that is all that has been attempterl.

While much that is given is the result of the anthor's own observation and experience, due acknowledgment is herewith mate of indehtedness to Thaddeus Norris's "American Angler's Book;" Professor spencer C. Baird ; Clark's "Fishes of the East Atlantic Coast ;" Scott's "Fishing in American Waters;" Goode's "American Fishes," and Henshall's "Book of the Black Bass," for valuable information.

Indulging the hope that this bantling of some of the author's leisure hours will fulfil the intention of its preparation; that it will somewhat aid amateurs in their endeavors to become skilful anglers, and that veterans will find in it something to interest and amuse, if not instruct, it is respectfully derlicated to them all.

Philadelphia, May 20, 1889.

A. M. S. 


\section{"NEAR-BY" \\ FRESH AND SAL'T WATER FISHING.}

\section{FRESH WATER FISHES.}

\section{The Past and Present of Angling.}

THE time was, and not very long since either, when there were 1 comparatively few amateur anglers or rod-and-reel fishermen in Philadelphia. The men who indulged in that healthful and pleasant recreation in this city twenty-five years ago, could almost have been counted on your fingers. Fishing tackle was then of primitive order, rods generally being of whole-stick bamboo, reels almost unknown and coarse cotton or hempen lines, poorly made and very kinky, instead of the fine cable-laid and braided silk and flax ones of to-day.

\section{Near-by Fishing Twenty-five Years Ago.}

Fishing in those days was confined mainly to waters within a few miles of the city, and most of it done with the now almost abandoned and unsportsmanlike hand-line. Here and there could be found some ardent lover of piscatorial sport who had the means, the time and the pluck, to venture across the sands of New Jersey to the seashore, but the rank and file were forced to content themselves with such sport as could be had in the Delaware and Schuyl- 
kill and their near tributaries, where they found perch, striped bass, "catties," sunfish and a few other kinds. In those days, fish were more abundant in the waters named than now, so that those anglers, primitive as was their tackle, would generally bring home good, big strings.

\section{A STep in ADVANCE.}

With the advent of railroads and steamers, came, of course, increased facilities for reaching more distant fishing points. The inchoate anglers in the near-by streams, began to learn something about the superior attractions of those more distant waters, of the larger fish and the larger catches. Thaddens Norris and a few others, took the ground that angling was an art, and wrote and spoke of it as something worthy of cultivation, and of the rod and reel as vital essentials to the proper prosecution of it. Converts to their advanced doctrines were not immediately numerous, but that fact, instead of discouraging, only seemed to incite to greater effort. They were of course ridiculed by the old-timers-those who clung to the hand-line and the unjointed bamboo rod. The idea of taking fish with devices that would give them a chance for their lives and, at the same time, afford the angler the sport of "playing" before landing them, was regarded with a feeling akin to contempt, and the few who eschewed the old and adopted the new derices were known only as "fancy fishermen."

Rod and ReEl Excroachunets on the Hand Line.

As skill in the use of the rod and reel and in casting, has generally to be acquired by experience, those who adopted what was then regarded as innovations, were at first, awkward in the use of them, usually unsuccessful, and, of course, laughed at by their less progressive brother fishermen. The writer remembers well, a day's perch fishing at Betterton, some twenty years ago, 
with that veteran angler and author, Thaddeus Norris, who, on that occasion, fished in those deep waters with so much less labor and with so much more success than I with the hand line and half-pound dipsy, I was led to think that, notwithstanding my oft expressed prejudices, there was, after all, something in rod fishing worth cultivating. When my companion-who, by-the-by, was the best rod-maker in the conntry-kindly offered to present me with a rod of his own manufacture, the offer was gladly accepted, and then and there, as far as I was personally concerned, the handline was discarded forever, though my first experience with the rod and reel was anything else than encouraging. The line would overrun and become almost hopelessly entangled, and just when the fish were biting most vigoronsly, my beard, which was then of the flowing order, would get wound up with the line. I handled the new tackle pretty much as a lady would a marlinspike, but perseverance conquers all things, and perseverance was finally rewarded with success.

\section{IMPROVEMENTS IN TACKLE.}

Gradually, but certainly, the rod and reel continued to grow in popular favor. The long, heavy, unwieldy, unjointed bamboos were superseded by the shorter, more flexible jointed ones, the weight being reduced until the minimum of the standard is to-day less than six ounces, the prices ranging from fifty cents to five hundred dollars. The ill-constructed brass reels of those days have given way to others of the most ingenious construction and elaborate finish, costing anywhere from one dollar to fifty or sixty. The coarse cotton or hempen lines then in use have been laid aside, except in out-of-the-way localities, and in their stead are the lighter, more costly and splendidly made silk and flax braided and cable-laid ones. In a word, there has been an almost entire revolution in anglers' outfits. They can be had of every quality, and, of course, at almost every price, the quality and cost depending upon the taste and purse of the purchaser. 


\section{LARGE VARIETY OF MODERN TACKLE.}

Twenty-fire years ago, the stock of fishing tackle kept on hand in the most extensive establishments in that line, was comprised mainly of a small assortment of roughly-made and poorly-tempered hooks, lines of indifferent quality, gaily-colored floats and a bundle or two of bamboo rods of various sizes, just as they came from the jungles in which they were grown. Now, fishing tackle stores are attractive, not only to anglers, but to all who are interested in neat and tasteful devices for taking the finny tribes. Large show cases fairly glow with polished reels of all sizes-of German silver, nickel, brass, rubber and other suitable material, and some of them with wheels and pinions so accurately adjusted and so finely finished as to be almost noiseless while running. American inventive ingenuity seems to liave almost exhausted itself in endearors to produce this now necessary adjunct to modern angling, as near perfection as is attainable.

As to hooks, they are alunost endless in variety, quality and price. There are the Kirby, the Limerick, the Aberdeen, the O'Shaughnessy, the Sneck Bend, the Kinsey, the Carlisle, New York Trout, American Bass, Sproat, Centripetal, Central Draft, Virginia Hollow Points, Sheepshead, Chestertown, Black Fish, Cod, Harrison, Barbless and a host of others, from the minutest and most delicate trout size to the formidable affair used for taking the biggest sharks.

Then there are cases of artificial flies of all conceivable colors, sizes and styles, gaudy and plain, suited to all seasons and waters, and to all fly-taking fishes, for bass, salmon, trout, etc. A catalogue of one of our principal tackle houses contains a list of more than 300 varieties, all of them elegantly and artistically made.

\section{Artistic Rods.}

Then come the rods, fashioned for all kinds of fishing, from the short, stont, heavily-mounted Tarpum or Silver King, to the most 
delicate trout rod of six or eight ounces, with tips so slender that only an expert can conceire the possibility of their being used successfully in the capture of four, five and six pound bass and trout.

\section{Fine Lines.}

The displays of fine fishing lines are marvels of superior workmanship, illustrating in a marked degree, the decided progress Americans have made in that special department of manufacturing. They are of cotton, hemp, flax, silk and sea grass, most of them notable for their remarkable strength and beauty of finish. A Cuttyhunk cable-laid line of the smallest size-not larger than a common sewing thread-defies attempts to break it without the risk of cutting the fingers to the bone. Some are cable-laid, hundreds of yards in length and without a single perceptible inequality; others are braided, and others still enamelled, to protect them from the rotting influences of the water. In Europe, American lines are given the decided preference.

Floats in great variety, spoon bait, spinners of an hundred forms and of the gaudiest colors, dipsies of all shapes and weights, ranging from a pound to the fourth of an ounce; nets for shad or minnow, for hauling, drifting or setting ; squids for blue-fislı trolling, gut snoods and leaders for casting, bait-pails, tackle-books and cases, fly-books, gaffs, artificial minnows, helgranites, frogs, crawfish, shrimp, etc.,-so closely imitating nature as almost to deceive a humnan being, much less a fish ; wading pants and boots and hundreds of other things, novel, useful and otherwise, are to be found in the varied collections.

\section{What This Fine Tackle Means.}

These large aggregations of ingenious inventions of skill and taste in the manufacture of useful and non-useful things, all serve to indicate the strong hold which angling has upon the popular heart. They are the responses to the constantly increasing demand 
for the best-made and most effective devices for killing fish without infringing statute laws. There is no recreation so almost universally indulged wherever and whenever opportunity offers; no stories so thoroughly relished as fish stories, and none in which exaggeration is said to so largely predominate.

Fortunately or unfortunately, numerous as are those who desire to be ranked with the disciples of Isaak Walton, only a few of them, comparatively, are able to practically gratify their inclinations in that direction. Hundreds-we were about to say thousands-are compelled to limit their fishing proclivities to the few holidays that occur during the warm months-Decoration Day and Fourth of July. There are many others who can occasionally take a day off and go fishing, and who would do so if they knew ahere to go with reasonable prospects of success, and what kind of tackle and bait to provicle for such brief outings.

So I have thought it may prove useful to consider the subject of " near by" fishing localities-places that can be readily reached by early trains or steamers-with the kind of fish found there, the proper tackle for taking them, the bait suitable, the lawful season, etc. This will embrace both fresh and salt water fishing, and will possibly prove interesting to the general reader and valuable to those who would like to go a-fishing occasionally, and would probably do so, if they but knew what provision should be made for the excursion.

NeAR-by Fresh Water Fishing Fifty YeArs Ago AND Now.

Fifty years ago, apprenticeship indentures in certain sections of Pennsylvania, but especially along the Susquehanna, contained the proviso, that fish should not be served to apprentices more frequently than a specified number of times each week. That curious provision owed its origin to the fact that edible fish were so plentiful in that river and so easily taken, as to have been an almost every day article of diet, and were fed to apprentices, until they 
were completely surfeited with that kind of animal food. The legal proviso referred to, then became indispensable, and the boys thereafter enjoyed its protective influence. It needs not the saying that no such protection is required now, and that if apprentices were indentured as formerly, there would be no occasion for the insertion of such a restrictive clause in their indentures.

\section{IVANTON DEPLETION OF STREAIIS.}

The inference to be drawn from the fact stated is, that within the memory of men now living, the waters of Pennsylrania so teemed with wholesome fishes, that they constituted a principal part of the food daily served at the tables of those who lived in the vicinity of any of the principal streams ; but, for reasons that are obvious, no such old-time fish-plentifulness now exists. The streams referred to, and the fishes contained in then, were regarded as public property, every man claiming the right to kill as many of the fish as he wished, whenever he pleased and by whatever means he might see proper to use. The result can readily be conceived. Year after year the fish products of the streams diminished, until, from many of the waters, fishes indigenous to them, almost entirely disappeared, and in face of the fact that stringent laws for the protection of the comparatively few remaining, were enacted, and liberal appropriations for the artificial propagation of valuable kinds and the restocking of the depleted streams made, by the Legislature.

But for that wise foresight, there would scarcely be left a remnant of the former abundance of native fishes. A more vigorous enforcement of the State fishery laws within the past five years and the stocking of the principal rivers and creeks with new and valuable varieties, have served to repair, in some degree, the damage done by the illegal crusades of former periods so mercilessly waged against fishes of all kinds; but the evil is not yet wholly remedied. Much remains to be done before the once noted prolificness of our rivers, creeks and lakes is restored. 


\section{HOW TO REPLENISH THEM.}

As this book is intended for the use of anglers of all gradesthe novice as well as the professional, the awkward as well as the skilled in the use of the hook and line-a word with them. If you are an angler or desire to become one, bear constantly in mind the fact, that one of the first essentials of a true angler is, to respect the claims of the fish, for they certainly have claims upon your consideration. While at times you play the part of an enemy to then, there are other times when you are in duty bound to act as their protector, and your duty cannot be more concisely and yet nore comprehensively summed up, than you will learn from a careful perusal of the fishery laws of the State. Obedience to their mandates is the single, simple requirement. Respect the close seasons, frown down everything that is illegal whether the illegality takes the form of killing fish out of season, or of killing them at any time, by the use of devices of the kind forbidden by the statutes. To catch or kill fish for mere sport, is barbarism coupled with a wanton disregard of the rights of others and of the laws of the Creator. If you chance to capture a "fingerling" of which you can make 110 profitable use, release it from the hook and return it to the water, handling it as tenderly as possible. If you must count your catch, the little fellow you have released will count all the same, and you will feel better satisfied for having done so, than if you had him in your creel, but ashamed to show him for fear of being laughed at. Follow out these easily observed rules, induce as many others as you can to imitate your example, and you will not only have performed a plain duty, but will have aided to some extent, in replenishing the nearly empty streams.

If our waters are nearly barren, the fault is not with them nor with nature's prorisions for the restoration of their former fertility. Wherever such barrenness-whether partial or general-prevails, it will be found, upon even casual investigation, to have resulted from gross violations of the laws of nature, and of the fishing laws of the State. 
How the State and Nature's Laws are Violated.

It would be superfluous to point out in cletail the varied forms those violations take. Among the many, may be named the pollution of the waters, the use of such devices as fish baskets, weirs, fyke nets, dynamite, and other methods resorted to by unscrupulous persons; the disregard of the spawning periods of the fish, etc. Glaring as these practices have been, and damaging as they are to the general public, the fact appears to make no impression on the minds of the transgressors. The laws are evaded whenever it is possible to do so without detection. In many cases that have come to the notice of the writer, public officers, sworn to enforce the laws relating to fish protection, have, instead, been found aiding and abetting their violation.

\section{NEAR-BY FishING IMPROVING, BUT NOT AS GOOD AS IT SHOULD BE.}

In view of the facts briefly recited, it is hardly necessary to state that " near-by" fishing in Pennsylvania—and for that matter, in New Jersey too-although better than several years ago and still improving, is not as good as it might and certainly should be. But there is happily, a better time coming. Every day, the rights of the fishes are being more and more fully appreciated and respected. Public sentiment has reached the conclusion, that the time has come when a proper regard for the fishery laws must be exercised by all, and if that sentiment shall continue to spread and strengthen, the day is not far distant, when our waters will again teem with abundance.

But despite their present comparative unproductiveness, those who are possessed of the proverbial patience of the angler, who are skilled in fly-casting, who relish a days outing with its wading and its climbing, or who prefer to try conclusions with the bigger fishes of the sea and the estuaries, can hardly fail to be rewarded with some "glorious nibbles," and, not improbably, return at 
night with well filled creels. Quite a number of our angling friends are favored in the latter respect, and with a view to the aiding of less experienced ones, who are not familiar with the "best places," it is proposed to furnish them with such information as will enable them to have a day's fishing that will be satisfactory, prefacing such information with brief descriptions of the principal luretaking fishes to be found in the localities named.

\section{THE PERCH FAMILY. \\ (Percida.)}

It is a fact not generally known, that the Perch Family Perci$d a$, includes more game fish than all the other fish families combined, as far as American waters are concerned. "De Kay claimed sixty genera and a hinndred species as belonging to it." An old and distinguished ichthyological friend of the writer, the late

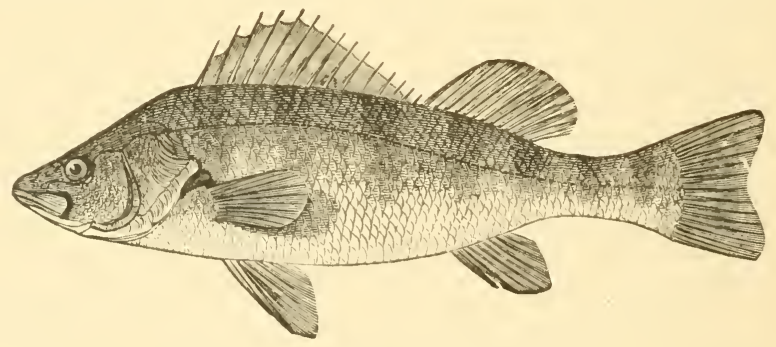

Yelilow BARRED PERCH.

(Perca fluiratalis.)

lamented Thaddeus Norris, author of the American Anglers' Book, the best practical book of its kind-says, "if by any dispensation of providence, the percoids should become extinct, there would scarcely be any sport left for the anglers who fish in the numerous creeks, rivers and lakes where they now abound:-Beginning with 
the Yellow Barred Perch, we have the White Perch, Striped Bass, Black Bass, Oswego Bass, The Sunfish, Bream, Buffalo Perch, Wall-Eye Pike and others of lesser note, all embraced in this big family and all of those named, found in greater or less abundance in " near by " waters, the type of them all being the

\section{YELLOW BARRED PERCH,}

which are found in most of the Northern lakes, and in moderate numbers in some of the tributaries of Chesapeake and Delaware Bays.

The Yellow Perch is taken readily with minnow or worm bait, though it is not noted for daintiness of taste. Comparatively few fishermen entertain special regard for this fish, being disposed to look upon it in the light of an interloper, with few claims to respect either for gameness or edible qualities; but there are others who entertain different feelings for them.

The Vellow Perch las very wide distribution, being found in all the waters of the Atlantic slope, in the lake region of the Northwest, the upper part of the Mississippi valley, and in most of the waters of the IVestern States. It is not abundant in any of the waters of Pennsylvania, though at times, it is captured in the Susquehanna. Of gregarious habits, it is said that when a school of them is met, the angler, if he is wary and quiet, may capture the entire lot. It is the deadly eneny of carp and trout, and hence should be carefully excluded from ponds containing those fish.

The Yellow Perch, although a roracious feeder, is not by any means a swift morer. Its movements are deliberate, even when in pursuit of minnows. Nor is it noted for gameness, though when fished for with light tackle, a one or two pounder affords not a little sport.

\section{Its Many Good Qualities.}

As to its table qualities, opinions differ, some repudiating it entirely, while others laud it highly. Seth Green styled it a 
"superior table fish." It is exceedingly graceful in its movements and in point of beanty, may be fairly regarded as one of the handsomest of American fishes. Frank Buckland says of it:- "Our friend, the Perch, is one of the most beantiful fish which it has pleased providence to place in our waters. Not only does he afford the angler excellent sport, but to the professed cook, his arrival in time for the menu, is most welcome, as witness water douche served at ministerial dimners," and G. Browne Goode says :- "I venture the prediction, that before many years, the Perch will have as many followers as the Black Bass anong those who fish for pleasure in the waters of the Eastern United States. A fish for the people, it is, and it is the anglers from anong the people, who have neither time, money nor patience for long trips and complicated tackle, who will prove its steadfast friend."

\section{HABITATS IND TACKLE.}

The Yellow Perch is found in nearly all the "near-by" streams, that are not too rapid. It is sometimes taken in considerable number and of good size in Bohemian river, which empties into the Chesapeake a few miles north of Betterton; but it is by no means certain that the angler will always be well rewarded for his efforts there. Lake Hopatkong in Upper New Jersey, abounds with Yellow Perch of large size.

Light tackle should be used, and when the water will admit, a float can be advantageonsly employed, being so adjusted as to keep the hook suspended about a foot from the bottom. They are most active and feed most vigoriously when full of spawn, and are said to possess their finest flarour when taken in that condition.

\section{THE WHITE PERCH.}

No one of our native fishes is more familiar to fishermen generally, whether amateur or professional-than the White Perch. It 
is one of the most abundant as it is also one of the most vigorous of biters, and among the very best for the pall of all our fresh water fislies. True, it is not the equal in gameness or edible qualities of the Striped Bass, but is, notwithstanding, a general favorite, especially with fishermen of the embryonic order, though for that matter, many of those of more matured experience and tastes, generally have a soft sicle for this congener of the more voracious and pugnacious Striped Bass.

\section{HABITATS OF THE WHITE PERCH.}

The White Perch is found in nearly all the fresh and brackish waters within easy reach of Philadelphia. It is not unfrequently taken considerably above the tide terminus, in the Delaware river,

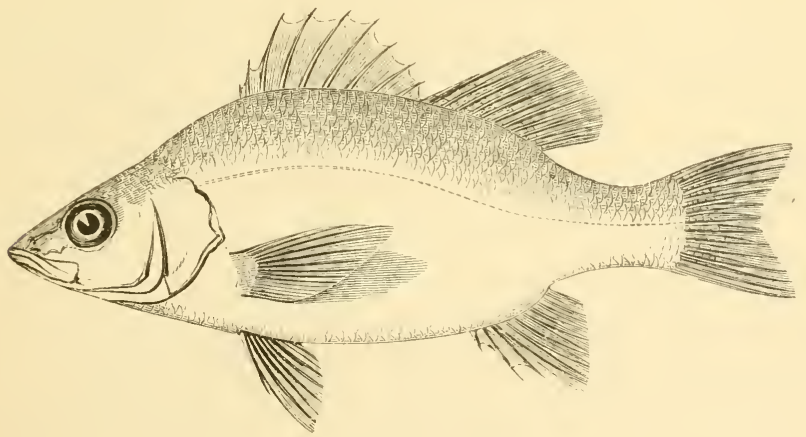

THE WHITE PERCH.

(Labrax Pallidum.)

though it may be properly called a fresh-tidal-river fish. Sometimes, perch are much more abundant in fresh than in brackish waters, though as a rule, the largest ones are taken where their native element is somewhat briny and deep. 
BetTerton TWENTy Years Ago.

Twenty years ago and more, the first "near-by" catches of perch, were made below the Fairmount dam, but being a fish of clean tastes, it now rarely ventures through the polluted waters of the Schuylkill to that once notable fishing locality. Twenty years ago, had the question been asked, where White Perch of the largest size and in greatest abundance could be found, the answer would have been, Betterton, at the mouth of the Sassafras river, in Kent county on the Eastern shore of Maryland. But the glory of Betterton has largely departed, as far as perch fishing is concerned. A catch of five, six or seren hundred in a day, by a pair of skilful handlers of rod and reel, was nothing uncommon, and the majority of such a catch, would range in weight from three-quarters of a pound to a pound and a quarter. But fyke nets, seines and other ruinous devices, have liad their legitimate effect-that of having either depleted the original stock, or driven it away to other localities. When tide and weather favor, a good many perch can still be taken at Betterton, but nothing like the number that would have rewarded the angler's skill a score of years ago. Betterton can be reached via. the Philadelphia, Wilmington and Baltimore Railroad, to Clayton, Delaware, thence to Still Pond, and from that point by carriage; or, by the Ericson Steamboat line, which leares every afternoon at four o'clock.

\section{Other NeAr-by Perch Grounds.}

In the vicinity of Spesutia island at the head of Chesapeake Bay, a few miles below Havre de Grace, there is generally good perch fishing, as also at Port Deposit and the other points on the Susquehanna river that will be referred to in connection with Striped Bass fishing.

Nearer home, from Port Penn at the head of Delaware Bay, to considerably above Lambertville on the Delaware river, at the mouths and generally a good ways up all the tributaries of that 
stream, White Perch are found. They come early in the spring, feeding greedily on the spawn of other fish, especially that of the shad; do their own spawning in May, and then usually retire to the deeper water to recuperate, after which, they return to their former favorite haunts, which are generally deep-sunken wooden piers, decaying wrecks, the timbers of old bridges or where there is sandy or rocky bottom. They are most readily taken on the ebb tide in the deeper waters, resorting on the flood, to the long grasses that grow on the shallow margins of creeks, and among the water-lilies, beneatl the pads of which small minnows seek protection from their relentless pursuit.

Among the streams on the Jersey side where the perch abound in their season, are the Rancocas, Coopers, Timber, Woodbury, Salem, Cohansey and Alloways Creeks, and Maurice River. The perch ascend the streams named, early in the season, and are usually of large size. All of them can be reached by the West Jersey Railroad and its several branches. The Neshaminy and the Brandywine, near their mouths, also abound with them.

\section{BAIT.}

While the perch has-as all fish have-its diet preferences, it is largely omnivorous, as far as animal food is concerned. It will take with equal zest, shrimp, soft-crab or earth worms. The larger ones dote on minnows and sturgeon spawn, and when bait of the kinds named is scarce and the fish plentiful, they can be readily tempted with little strips of cut fish, with a portion of the skin adhering.

\section{TACKLE.}

Light tackle is of course the only kind that should be used. A short pliable rod, multiplying reel, the thinnest possible strong line, single gut snoods, small hooks, three on the line at snood-length distance apart, with just enough sinker to carry the line to the 
bottom and keep it there. Some prefer the almost obsolete hand-line, others that most unsportsmanlike contrivance, the bowline; but the fisherman who does not desire to be classed with the " pot-hunters," will never think of using either.

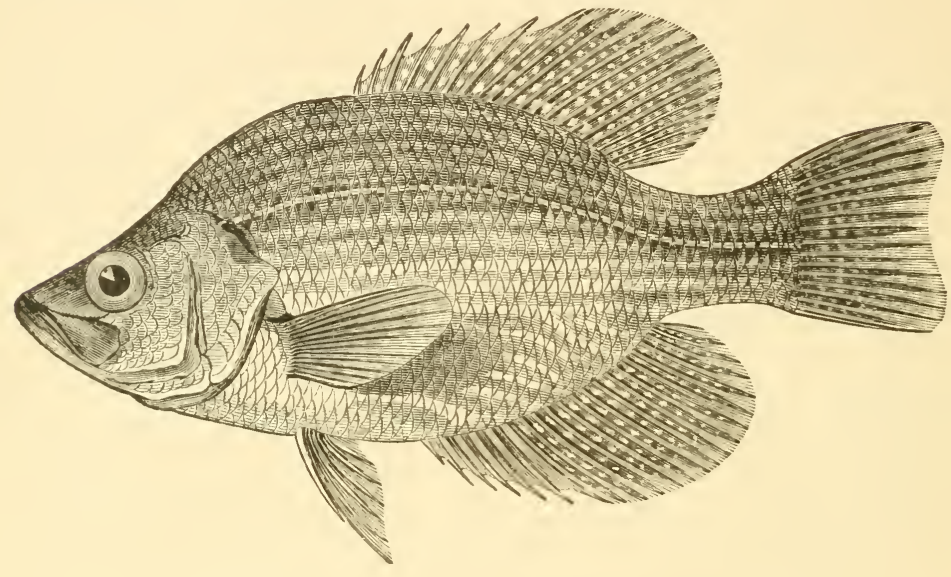

CHINQUEPIN PERCH.

This beautiful fish rarely finds its way into Atlantic slope waters. It is abundant in W'estern and Southern waters and in the Atlantic States South of Cape Hatteras, where it takes the minnow, or a small bit of cut fish, and where shrimp abound, is partial to that kind of bait. Its presence is so rare here, that there is no occasion for particulars as to the style of tackle and methods of fishing for it.

\section{THE SUNFISH, OR MOCASIN.}

This lively little member of the perch family is almost ubiquitous in the waters of the Atlantic slope, and is a general favorite with "near-by" anglers, as it is a vigorous biter, and is moreover, 
when of good size, an excellent pan-fish. 'That the Sunfish, or "Pumpkin seed" will readily take the fly, can be demonstrated by a visit to Spesutia Island at the head of Chesapeake Bay, where they are known as the Mocasin, and sometimes attain the weight of half a pound. They are found there in the greatest abundance in what is known as the "Narrows," a strip of water between the western side of the island and the main land. They can also be taken in large numbers in the North East River, which, like Spesutia Island, is reached by the Philadelphia, Wilmington and Baltimore Railway.

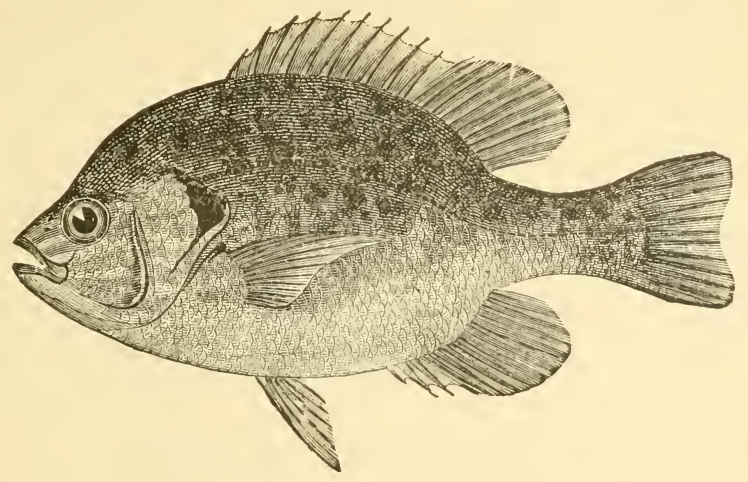

The Sunfish, or Mocasin.

(Pomotis rulgaris.)

The Editor of the American Angler says of the Sunfish:- "I confess to a fondness for catching the "Pumpkin seed" wpon the lightest of light fly rods, and almost spider web consistency. I have caught them averaging half a pound in weight by the dozen, with black and brown hackles, and when they reach that size, they are so sprightly in their play, when hooked on trout tackle, that we cannot deny them a niche in the gallery of game fishes."

It is hardly needful to state that the lightest kind of tackle 
should be used, and as the "sunnies" are almost invariably found in quiet waters, a float is necessary, and what the boys call a "flyhook, " baited with an angle worm or a bit of dough bait.

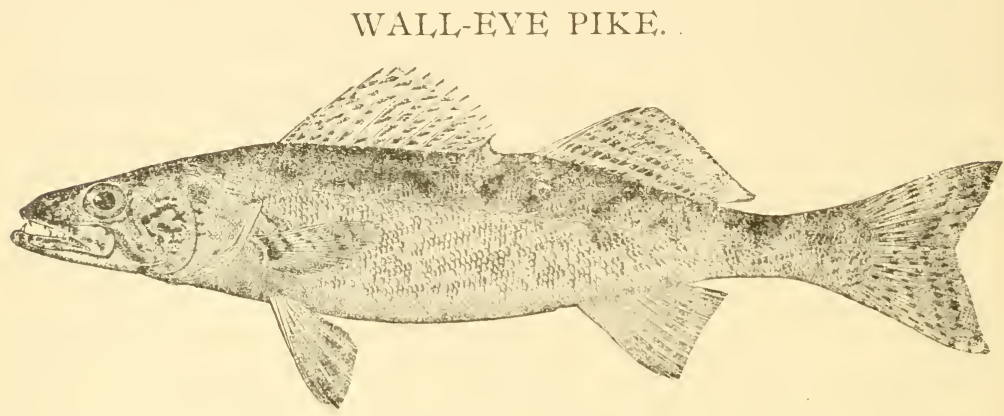

The Perch Pike, Susquehanna Salion.

(Stizostcdion vitrcum.)

When this fish was introduced into the Susquehanna, or whether it is indigenous to that river, are matters of less moment than whether it is valuable as a food fish, and whether the angler will find in it a rariety that will afford him sport. It is found in the Susquehanna river, that and the Juniata being the only streans east of the Alleglianies, in Pennsylvania, in which it is well known. There, it has become noted for its gameness as well as for its superior table qualities.

\section{Not OF THE SALMON FAMILY:}

From the fact that with a great many persons, the Wall-Eye is known only as the "Susquehanna Salmon," a natural inference would be, that it is one of the Salnon family; but such is not the fact. It has none of the distinguishing characteristics of the salmon, its flesh being white instead of pink, though flaky and of fine flaror. 
It is also found in great abundance in all the great lakes, ranking in commercial and table importance next to the White Fish and the Lake Trout.

\section{Preparations For its Artificial Propagation.}

The Pike Perch, or "Wall-Eye Pike," is one of the most voracious of feeders, preferring live food. It is readily susceptible of artificial propagation, and, it will, no doubt be agreeable news to anglers generally, to learn that the United States Fishery Commission is arranging to take and hatch about one hundred millions of the eggs of it at the Sandusky Hatchery, during the present spring, and that a large proportion of the fry-not less than I 2,000,ooo-have just been planted in suitable streams in Pennsylvania, prominent among which are the Susquehanna, Delaware, Schuylkill and Lehigh rivers.

\section{GAMEY, AND MERITING PROTECTION.}

At present, the Wall-Eye Pike, so called because of its distinctively marked eyes, is found in many localities in the Susquehanna river in considerable abundance, and is mainly taken with minnow bait. It delights in clean, clear, rapid streams, frequents the vicinity of sunken logs, etc., and is one of the gamest of our fresh water fishes, taking the lure readily, and disputing supremacy with the angler to the last gasp. It is an exceedingly prolific fish, and if the laws for its protection had been observed as they should have been, the plant made in the Susquehanna at some former period, would have so multiplied, as to have caused the waters of that river to fairly teem with it. It spawns in May and June, and it is a matter of regret that the spawning beds are so frequently invaded with seines and other devices, which invasions have had the effect of serionsly interfering with its increase. As there is every probability of a more rigid enforcement of the fishery laws in the future, there is room for the hope, that the proposcd 
re-stocking, by the United States Fishery Commission, will have the effect of making them plentiful in all the rivers mentioned.

When found in swift rolling waters, under falls, it is said to be the master of the Black Bass, but in smoother water, the general supremacy of the latter is maintained.

The Wall-Eye is charged with derouring its own young, as well as the young of other fishes, and though this is to be regarded as a most serious fault, it has so many other redeeming qualities, that it should be pardoned for such vicious tastes. G. Browne Goode quotes an ardent admirer of the Wall-Eye, who says of it: "Look at this beautiful fish, as symmetrical in form as the salmon. Not a fanlt in his make-11p. Every fin perfect, tail clean-cut, and his great big wall-eyes stand out with that life-like glare, so characteristic of the fish."

\section{Prolific AS Well as Ginet.}

That the I'all-Eye is prolific there is nndisputed evidence, and if the laws enacted for its protection had been decently observed, the proposed stocking of the Sinsquehanna would be superfluous.

According to statute law, the Wall-Eye Pike, Bass and Pickerel may not be taken during the months of January, February, March, April and May, "nor at any otler time, than with hook and line, scroll or spear." The penalty for each violation is ten dollars.

The "best places" for Wall-Eye Pike, in the Susquelıanna, are so numerous as to render a list of such localities impossible, with the space at comminand. The angler will not be likely to go astray, however, who selects any of the well-known fishing points between Port Deposit and the upper waters of the stream, taking in both branches of the river, and including the lower portions of the Juniata. On the river between Dauphin and Steelton, above Harrisburg, are several noted places, and below the dam at Sunbury many are taken. 
TACKLE AND BAIT.

Regular Striped Bass or Black Bass tackle, such as is needed at the mouth of the Susquehanna, will answer. Use a float, and if fishing from a boat, anchor it by the side of or above a rapid, and let your bait float down through the swift water to the foot of the rapid. As already stated, live bait is its weakness, though it feeds greedily upon larvæ, crawfish, small frogs, tadpoles and worms.

\section{THE STRIPED BASS OR ROCK-FISH.}

\section{(Labrar lineatus.)}

Among the most esteened-perhaps the foremost of our indigenous fishes in " near-by" strean1s-is the Striped Bass or Rockfish, which is found not only in tidal but in fresh waters also-the Susquehanna and the Delaware, together with their tributaries, abounding with them.

\section{Gamer QuAlities OF THE STRIPED BASs.}

Of the Striped Bass it can truthfully be said, that it is hardly inferior to the salmon, either in gameness or table qualities, while it is greatly its superior in point of beauty and abundance. Symmetrical in shape, handsomely marked, and built for speed and endurance, there are few fishes whether of salt water or fresh, that possess as many attractions for the true angler. There is nothing mean or sneaking about it. A roracious feeder, seemingly always hungry, it rarely hesitates about taking its prey, whether it be a live minnow swimming at large, a piece of salted eel-tail, a toothsome bait, or gaudy lures in the form of spoons and spinners, which modern tackle manufacturers have made so attractive to it. The angler, fishing in fresh waters in which Striped Bass abound, readily comprehends when a good sized specinien of that kind, takes hold. It becomes clearly apparent from the word "go!" 


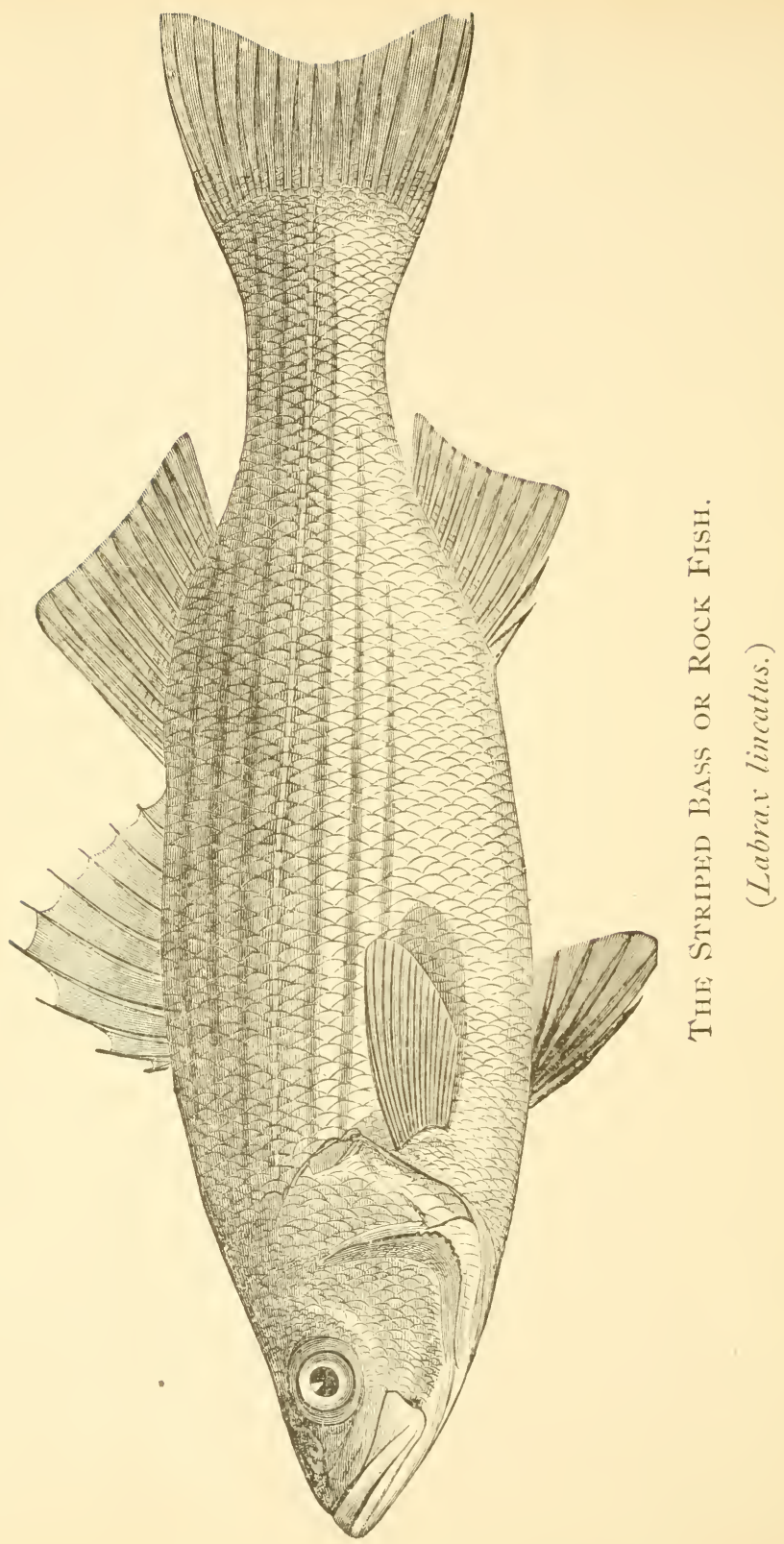


that business is meant, and that skill in handling him is required if his capture is to be made in anything of a sportsmanlike way.

\section{HOW IT TAKES HOLD.}

The morements of the Striped Bass are almost as quick as lightning, which, coupled with its great strength and remarkable powers of endurance, have given it a conspicuous place in the rank of game fishes, especially along the Atlantic coast, where there is constant eager competition among a certain class of roc-and-reel men, to win the enviable celebrity of having captured the largest. Of that competition, something will be said, when treating of salt water fishing. The first dash of the Striped Bass at the lure is tremendous, and his struggles to escape when hooked, such as fairly entitle him to admiration and respect.

\section{TABLE: QUALiTIES.}

The edible qualities of the Striped Bass are fully equal to those of the best food fishes, not even excepting the salmon. While some who profess to be connoisseurs in fish-eating, contend that a Striped Bass of less than twelve inches in length, is not fit to be eaten, there are many others who differ with them on that point, and who think it has few superiors for the pan. For baking or boiling, it is one of the acknowledged standards, aways commanding high prices and with a demand generally equal to the supply. Therefore, whether viewed from the standpoint of gameness, or that of table excellence, or both, this monarch of the fresh waters, deserves alike, the regard of anglers and gonmands.

\section{Habitats of the Striped Bass.}

As far as "near-by" fresh waters are concerned, the Striped Bass is found mainly in the Delaware and Susquehanna, and their tributaries. In the former, as far north as Lambertville, New Jersey, 
and in the latter, as far up as Columbia, where its further advance northward has been for years prevented by the dam that crosses the river at that place. Whether the facilities afforded by the recently constructed fishways in that dam will be availed of by it, is a question that time must determine. Before dams were built in that river, Striped Bass were taken as far north as Luzerne county.

\section{SOME OF THE BEST STRIPED BASS FISIING LOCALITIES.}

Perhaps the most noted Striped Bass fishing waters of the Susquehanna, are those in the ricinity of Port Deposit, about three miles from Perryville, via. the Philadelphia, Wilnington and Baltimore Railroad. At no other point on the river are they taken of such size and in such abundance. At times, the water fairly teems with them, twenty pounders being frequently hooked, though only experienced anglers would care to tackle customers of that size, and few others wonld succeed in landing them. Salted eel-tail is a farorite bait. The spoon or spinner, is also a taking lure, but a live minnow of good size is much more tempting, though not always as easy of procurement. Young catfish, tadpoles, helgramites, crawfish, and even ordinary earthworms, are not rejected by the smaller ones, in still fishing. Early in the morning, and from four o'clock in the afternoon until sundown, are the hours when Striped Bass are most apt to feed, and always take the lure most readily-especially if it be a spoon or spinner-when the water is clear. Make sure that the water is in that condition before you start, if you desire success.

The best season for Striped Bass fishing at Port Deposit, is during June and July, and as there are no legal restrictions there, fishing for either the Striped or the Black Bass may be indulged there at any time.

A little further up the river is Conowingo Bridge, where excellent trolling and bait fishing for Striped Bass can generally be had, also, at Bald Friars, a mile and a half further on. Four 
miles above the latter place, is Peach Bottom or Peters Creek, where there is generally good fishing as also at Fite's Eddy, four miles still further northward. Fite's Eddy is more notable for Black than for Striped Bass, but sometimes good catches of the latter are made there. In the rapids and eddies opposite and below Safe Harbor, Striped Bass ranging from half a pound to a pound and a half in weight, are frequently very plentiful, sometimes so abundant as to seriously annoy the Black Bass fishermen. Below the dam at Columbia they are usually taken of moderate size, and in fact, in the eddies at almost any point on the river up to the last mentioned place. All of the places named can be reached in a few hours either by the Philadelphia, Wilmington and Baltimore Railroad, or direct from Philadelphia, by the Central Division of that road, and by the Pennsylvania Railroad to Columbia and thence down the river.

WHERE S'TRIPED BASS ARE FOUND IN THE DELAWARE.

A few years ago, good Striped Bass fishing could always be had at Chester and Marcus Hook, but for some unexplained reason, they appear to have abandoned those localities.

Ascending the Delaware on the Pennsylvania side, they will generally be found at the outlets of the Pennepack and Neshaminy creeks, especially the latter, and at various other points as far north as Lambertville, where at times, they are caught in great abundance though not of large size.

On the Jersey side of the river, they will be found in seasonwhich is pretty much all spring and summer-at or near the mouth of the Rancocas, Cooper's, Timber, Woodbury and Salem creeks, at Port Penn, opposite Wilmington, and further down, in Maurice river. All of the places on the Delaware can be readily reached in a little while by rail or steamer; northward by the Pennsylvania, and the Camden and Amboy roads, and southward by the Philadelphia, Wilmington and Baltimore, or the West Jersey and its branches. 
The character of Striped Bass tackle should be made to conform to the waters to be fished, and the size of the fish frequenting them. Light tackle will answer in any of the localities named except Port Deposit, where, as Striped Bass of rery large size are often killed, it will be well to provide that which is moderately heavy. Ordinarily, single gut leaders will answer, but there is no objection to double ones, unless it be the cost, which is not heary ; and, unless you are after big fish only, let the hooks be of moderate size. Experienced anglers prefer those ranging from a No. I to a 2 or 3 , the size depending upon the run of the fish.

In fishing for Striped Bass in fresh as well as in salt waters, it is well to bear in constant mind the fact that that fish is not a nibbler. In gamin parlance, he does not "monkey" with the bait. Acting on the well-known principle that "the right way to do a thing is to do it," he rarely stands upon the order of his taking, but takes the bait and goes about his business, if you will let him. The startling style of lis first dash is apt to unsettle the equanimity of the inexperienced, and prompt to action far more vigorous than is needful or prudent. Rapid and inconsiderate reeling-in, is apt to follow, and not always with desirable results. Making haste slowly, is good policy if you are dealing with a large fish, and it must not be forgotten that the Striped Bass is not like the pike or weak-fish-furious for a moment and then subservient. He is built for strength and endurance and may be counted upon for a protracted fight. If the water admits, long runs may be looked for, and it is for such runs the angler should be prepared. Give him play, deal gently but firmly with him, and possess your soul in patience while wearying out your hoped-for prize. When at length he turns over on his side, giving unmistakable evidence of exhaustion, then, have your landing net or gaff ready and take him. The strike of a big Striped Bass is apt to affect the inexperienced angler pretty much as does the first glimpse of a deer, the hunter not accustomed to such sights. It unsteadies his nerves, and not unfrequently causes him to lose his head, and do unwise 
things. Therefore, keep on the alert always; expect a strike at any moment, and be prepared to deal with the striker cooly. Your rod should be of a make that will stand a heavy strain-not necessarily heavy, but so constructed that it will not be shattered by such heary pulls as big Striped Bass are prorerbial for making. You will want a good multiplying reel, and about one hundred yards of cable laid hempen line. A nine or a twelve-thread 'Cuttyhunk will answer.

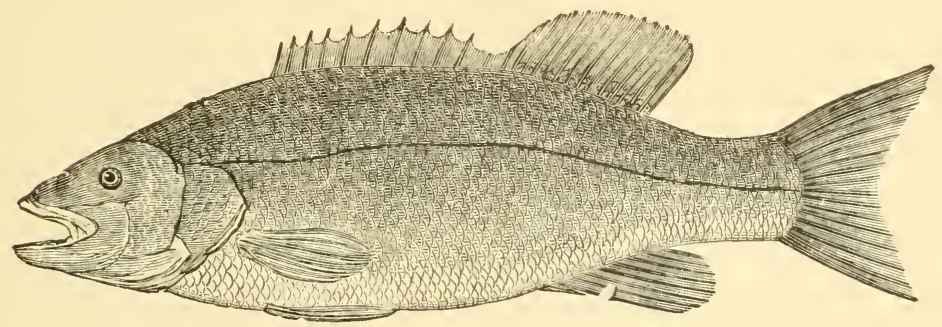

BLACK BASS.

(Microptents dolomien.)

This now well-known game food fish, forty years ago, was wholly nuknown to the New England States, and to the Atlantic seaboard of the Midddle States, a still shorter period. Dr. Henshall, the best authority on the subject says: "The original habitat of the species, is remarkable for its extent, for with the exception of the New England States, and the Atlantic seaboard of the Middle States, it comprises the whole of the United States East of the Rocky Monntains, Ontario, (Canada,) and East Mexico." From this it will be seen, that although a distinctively American fish, it is a transplant in our waters, though it has thriven wonderfully in them. 
INTRODUCTION EAST OF THE ALLEGHANIES.

The first record of their introduction dates back to 1850 , when twenty-seven were put in Flax Lake, Massachusetts. Subsequently, other lakes were stocked in nearly all the New England States and in New York.

In I 854, Mr. William Shriver of Wheeling, Virginia, planted a number of bass in the canal basin at Cumberland, Maryland, from which they escaped into the Potomac river, where they have since multiplied to such an extent, that the principal supply of Black Bass for the Philadelphia markets is derived from that river. They were brought to Cumberland in a live box, in the tank of a locomotive.

In I869, several private citizens of Harrisburg, planted a number of Black Bass in the Susquehanna, and four years later, the tributaries of the Susquelianna, Potonnac and Delaware Rivers, were stocked at thirty-five different points.

\section{RAPID INCREASE OF BASS.}

The foregoing highly interesting facts indicate in the most nnmistakable manner the readiness with which the food-fish supply can be increased in our waters. Thirty Black Bass fry, placed in the canal basin at Cumberland, in the short space of thirty-five years, have multiplied so largely as to have become a source of important revenue to the many fishermen of the Potomac river; and the public spiritedness of a few gentlemen at Harrisburg in 1869, has been the means of stocking the Susquehanna from its mouth to its head waters, with the same valuable fish. The same results have followed the placing of them in the Schuylkill and Delaware Rivers and their tributaries, in which good work the State Fishery Commissioners were greatly assisted by the "Anglers' Association of Eastern Pennsylvania," whose headquarters are in this city. 
A FACT TO BE REMEMBERED.

It should be borne in mind, in connection with the facts stated, that the present and constantly increasing abundance of this noble fish has been secured at a most trivial expense, and that the increase not only enlarges with each passing year, but, that this constant increment is without cost to the people of the State, other than the observance of the reasonable laws enacted for the protection of the Black Bass during its spawning season, and the prevention of what is known as illegal fishing at all seasons.

\section{A General Favorite With Avglers.}

Next to the Trout, the Black Bass is the favorite of Pennsylvania anglers generally, and, for a number of reasons, among which are the three following: (I) its remarkable gameness ; (2) its ommivorousness; (3) its adaptation to most of the streams of the State.

In regard to its gameness, it is to be said that there is not in the whole range of lure-taking fishes any fiercer fighter $110 \mathrm{r}$ any possessed of greater powers of endurance. It does not struggle for a brief season and then surrender, but figlits to the very last. It has been a matter of dispute with someleading anglers, which of the two, the Black Bass or the Trout, is the gamest. Taking Mountain Trout of equal size, it is fair to them to say, that they contest supremacy with the angler as fiercely and persistently as the Black Bass; but as between the latter and the Lake Tront, the Bass is fairly entitled to the championship.

\section{A General AND Vigorous FeEder.}

Another commendable characteristic of the Black Bass is the readiness with which it takes either fly or bait. Its favorite and presumably principal foods, are crawfish and minnows, with, of course, flies thrown in as a dessert. While young, insects and 
larvæ comprise its almost exclusive diet, but the adult bass, while greedily taking such small game, depends mainly upon the more substantial diet named, together with such other aquatic creatures as helgramites, tadpoles, young frogs, small catfish, and when offered them as lures, crickets and grasshoppers.

\section{NOT A DEPOPLlator OF THE STREAMS.}

One of the most prominent objections waged against the stocking of our streans with Black Bass, was the theory that their voraciousness would prove hurtful to the young shad, as well as to young fish of other varieties; but experience in Pennsylvania waters, as well as elsewhere, warrants no such belief. Referring to the voracity of the Bass. Dr. Henshall, who is to be regarded as the very highest authority on the subject, says: "The Black Bass is excelled by no other fish that swims for gameness, and among fresh water species by but one-the white fish-for the table. And further, he will not eat the spawn of his mate nor that of his fellowmates. His natural food is the crawfish and minnow; he prefers them and they are easily procured. On them he will wax and grow fat, increase and multiply. The man who alleges that he depopulates the streans of valuable food fishes, or asserts that he 'kills for the love of it,' has never looked into the mouth of a Bass with his eyes open."

\section{WhERE TO FiNd THE BLACK B.ISS.}

An enthusiastic and highly successful Bass fisherman informs us that as the stream.s tributary to the upper Delaware are the natural home of the Trout, the river itself lias become famous for its excellent Black Bass fishing. From Port Jerris to Hancock, every pool and eddy is tenanted by this unsurpassed game fish. Handsome Eddy, Pond's Eddy, Lackawaxen, Cochecton, Narrowsburg, Calicoon and many other places are first-class fishing points, and all accessible by the New York and Erie Railroad. 
Nearer home, there are many stations along the line of the Delaware, Lackawanna and Western, and Belvidere roads, where the angler can find fair bass fishing. At Portland and the Delaware Water Gap, Delaware, Manunka Chunk and Martinsrille are good pools. Below Easton are Carpenterville, Riegelsville, Milford, Byram and Trimble stations, where the river affords excellent fislining.

For any of the stations below Easton, the angler can take an early morning train from Broad street station, reach his destination before ro o'clock and return on an erening train the same day.

If distance lends enchantment to the piscatorial view, the fisherman can choose from many points on the Lower Susquehanna. Little Washington, three miles below Columbia, is noted for the excellence of its Black Bass fishing, as is also the Columbia dam when the water is low and clear.

Safe Harbor, McCall's Ferry, Fite's Eddy, Peach Bottom or Peter's Creek, Conowingo Furnace and Port Deposit, all yield good returns for skilful angling. The places named can be reached via the Pennsylvania and Columbia and Port Deposit roads.

In addition to the foregoing habitats named, these fine fish are also found in the Brandywine, the Neshaminy and other tributaries of the Delaware below Trenton on the Pennsy-1rania side; in all the larger tributaries of the Susquehanna, especially the Juniata, and in the Schuylkill and its lower tributaries, which include the Wissahickon and Perkiomen, with a number of other favorable points, as Royer's Ford, Lafayette, Shawmont and Flat Rock dam. Those who can spare the time, will find in Lake Hopatkong, N. J., three and a half hours ride from Philadelphia, all the sport they desire, not only with bass, but with pickerel, yellow perch, etc.

\section{OUTFIT.}

For Black Bass fishing, the best outfit is an eight or nine-foot, nine to twelve ounce rod, moderately springy and made of split 
bamboo. Competition has so reduced the price of these, that a fair rod can be had at from five to eight dollars-very little more than the cost of a good wooden one. The prices of the finer qualities of split bamboo rods range from $\$ 15$ to $\$ 50$, according to the reputation of the naker. Within a recent period, the manufacture of wooden rods has been so improved, as to be regarded by many anglers as equal, at least, to the rent and glued. They are less expensive, and can be made of any desired length. The Bethabara, Lancewood, Greenheart and Dgani woods are the kinds most used and most esteened for rods. Hornbeam is tough but not springy. The reel should be a nultiplier, with a check or drag large enough to hold fifty or sixty yarch of $\mathrm{G}$ waterproof enameled line. A rubluer reel is preferable because of lightness.

If the fishing is done with a float, a three-inch cork, barrelshape, is the best. The leader should be ahout four feet long and of strong gut. To one end of the leader a Pitcher's swivel sinker No. 9 or ro should be attached. Some anglers fasten to this a short leader two feet long, to which is attached the hook. A No. I or 2 Sproat hook is abont the size. The float can be dispenserl with, when casting in rapid or shoal water.

A landing net will be fonnd nseful, and if the angler is desirous to carry his bait with him, the Rudolph floating pail is the best. It has a clepression at the top, in which a small piece of ice wrapped in a towel can be placed, the dripping from which keeps the water cool. It can be attached to the boat or to a bush along the shore, obviating the necessity of constantly changing the water. The common tidewater minnow of the Delaware is a good bait, so is the small stone catfish, the helgranites. crawfish and lamprey eels.

With a good rod and tackle, plenty of bait and a good day and place for fishing, the resilt will depend npon the angler himself. 
Close Seasons in Pennsifinani and New Jersey.

The close season for Black Bass in Pennsylyania is fron the Ist of January to the Ist of June. In New Jersey it is lawful to take them with hook and line from the zoth of May to the Ist of December. The close season for seine or other net fishing in that State is from the rst of March to the Ist of May. It will be well for those who contemplate Trout or Black Bass fishing in New Jersey, and who are non-residents, to consult the Rules and ByLaws of the West Jersey Game Protective Society before starting.

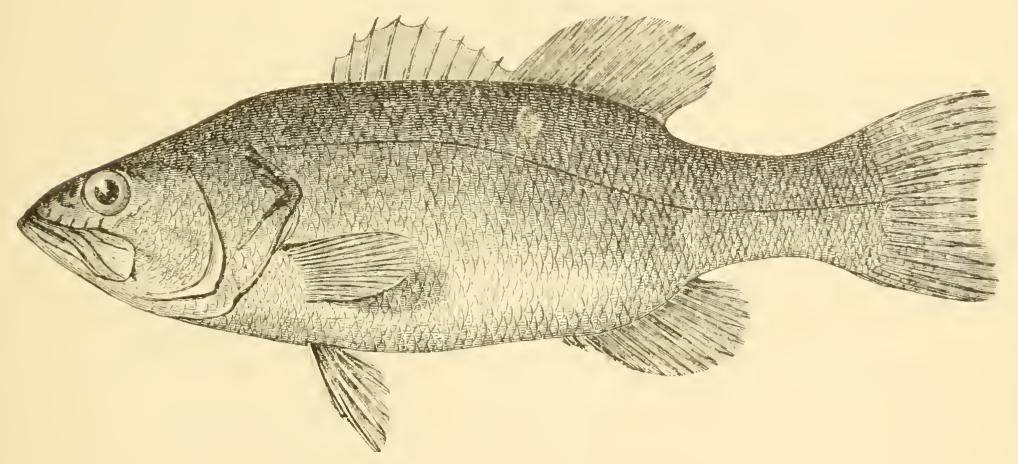

\section{LARGE-MOU'TH BLACK BASS.}

The marked stuccess which has attended the introduction of the Small-Mouth Black Bass, the German Carp and the Wall-Eye Pike into the waters of the Atlantic slope, has encorraged the State Fishery Commissioners of Pennsylvania to try a like experiment with the Fresl Water Bass of the South and IVest, faniliarly known as the Big-Mouth Black Bass. For sereral years past, the attention of the State authorities has been directed to this wellknown ganey fish, a very prevalent inpression being, that if our 
less rapid rivers, lakes and large ponds were stocked with it, satisfactory results would follow. Why not? Why should the BigMouth Bass fail in the Delaware and Schuylkill, and their several quiet tributaries, when it is remembered that, as Goode states, "the Large and the Small-mouths dwell together in the Great Lakes" ? Why not in our waters? It is one of the most wiclely distributed of our fresh water fishes, as it is the most abundant as far north as latitude $50^{\circ}$. fronn Florida to Manitoba, and as far north, eastward of the Alleghanies, as the James River. Neither it nor its near relative, the Small-mouth, is native to the eastern part of the Middle States, but the latter has made itself at home with us, and is evidently intended to be a permanent resident.

Every fresh water strean of any size in Southern or SouthWestern States is full of them, and althougln less ganey than the northen Small-motth, are nevertheless attractive sport for the anglers of the regions to which they are indigenous.

The Big-1Iouth Bass are taken with all sorts of lures, from a fly to the gandy spoon or spinner, and from a live minnow to a four or five inch mullet. Of roracions tastes, they allow themselves to be so closely approached in the lagoons, along where the lily pads flourish, as to be taken with what is called a "bob," which is a barbarous thougl very effectual method.

Looking confidently forward to their introduction into our "near-by" waters, and also conficlently anticipating entire success from the experiment, it will be as well to wait for their arrival and acclination before saying any thing about tackle, etc.

\section{THE ROCK BASS.}

This is another fish of comparatively recent introduction in the waters of Eastern Pennsylvania. It has a high reputation for excellence as a pan fish, is roracious, a ready and free biter and full of game. It is abundant in the great lakes, and is occasionally found in the Susquehanna, but is not plentiful at any point 
east of the Alleghanies. Its introduction into eastern waters is of such recent date, that the point has not yet been satisfactorily de-

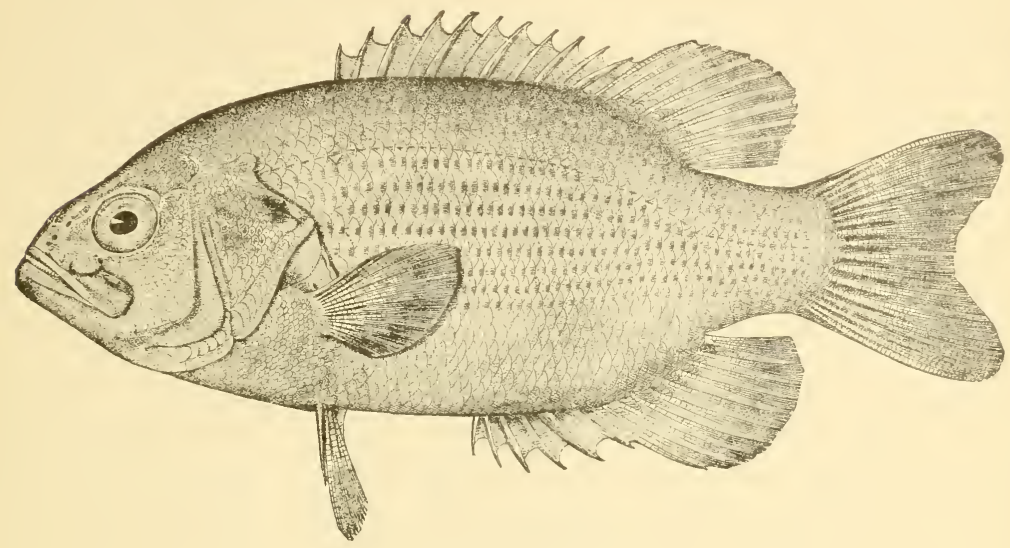

THE ROCK BASS.

(.tmbloplites rupestris.)

termined whether it will or will not prove prolific. It is of the Perch family, frequents sumken logs, roots of trees, etc., and is capable of propagation in ponds. The same laws that protect the other bass fishes apply to it.

\section{THE BROOK TROUT.}

\section{(Salmofontinalis.)}

Although the "near-by"' streams that once abounded in this superlatively game fish, have been entirely depleted of them, and the well-meant efforts of the Anglers' Association of Eastern Pennsylvania to restock them with other varieties of the same family adapted to such waters-the California and the Rainbow Trouthaive resulted in failure, it would be unpardonable to pass this general favorite withont at least brief mention. 


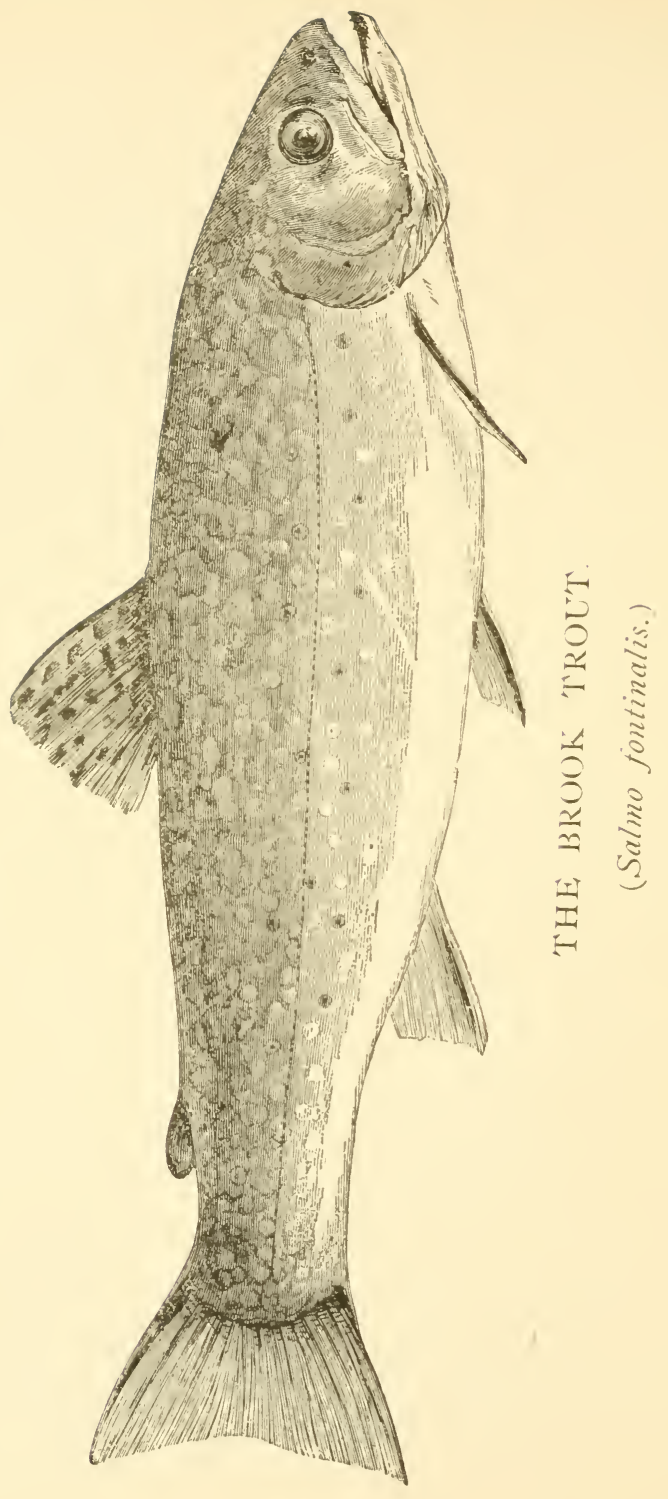


WHERE TROUT MIST BE SOUgIT

A whole chapter night be-in fact, whole books have beenwritten ahout this beautiful fish, once so abundant in many of the streams of the lower tier of connties, but because of the merciless warfare waged against them and the well-known illegal pollution of the waters, they hare become extinct, while all efforts to replace them with other varieties have proved unarailing. Hence, if the reader desires to enjoy the royal sport of trout fishing, he will have to seek his game in other than "near-by" streams. In almost any of the mountain streams of Northern Pennsylvania, in Pike, Monroe, Sullivan or Luzerne counties, he will find Speckled Trout in moderate abundance, and usually of small size, though occasionally he may be fortunate enough to capture some of the bigger ones. He will also find some in the connties of Centre, Mifflin, Blair, Huntingdon and Bedford, and a few in one. or two of the streans; of Cumberiand county.

\section{Why Trout ARE ScARCE.}

The open season in Pennsylvania begins with the 15 th of April, and ends with the I5th of July, though there are not a few persons who do not hesitate to set the law at defiance and take trout whenever opportunity is afforded then. Those who have a proper respect for law, bide their time, and cast their flies only when they can do so lawfully, and therefore, with clear consciences. Then, nearly every accessible stream that contains-or is supposed to contain-trout, is waded and whipped almost without intermission, until the interdict of the State fishery laws puts an end to it. Unfortunately, among those eager fly-casters, are many who estimate their catches by number and not by size or weight, and who are content with the ability to boast that they killed so many, though possibly their creels did not contain a single fish entitled to a prouder designation than that of " fingerling." Such fishermen are simply "pot-hunters," and the aversion of all true anglers. 
It is not surprising therefore, that trout of respectable size are so scarce in our State streams, or that the annual restocking of those streans from the State Hatcheries has failed to increase the number beyond the thousands of fry from year to year placed in them, and which are almost certain to be captured and killed before the next installnent is planted.

A few tront are said to be fonnd in one or two lonely streams within a few miles of Canden, but the number is so linited and the streams so encumbered by bushes and other undergrowth, as to render the fishing of them next to impracticable. The open season in New Jersey is from the 1st of March to the Ist of October.

\section{TROLT OTTFITS.}

As to the ontfit needed for tront fishing, it is composed of so many esisentials-essentials in the estimation of a regular trout angler-that it wonld reguire more space than can be spared to enumerate them. Any of the comprehensive illustrated catalogues of the leading tackle houses-which can usually be had for the asking-rill supply the desired infornation, though it is hardly needful to state that a majority of the so called essentials could readily be dispensed with.

\section{THE TroetT Regions OF PFNASTLVANI.}

A thorougly informed trout fislerman has kindly furnished the following points, which will prove interesting and valuable to those who think of visiting the trout regions of the northeastern comties of the State, but who are not faniliar with the streans of that territory.

The nearest to Philadelphia, of good trout fishing, is probably at Henryville, Monroe county. This point is reached by the Pennsylrania Railroad to Manunka Chunk, connecting there with the Delaware, Lackawanna and Western road. There are several good streans in the immediate vicinity, tributary to Broadhead's Creek. 
Eight niiles further north, on the last mentioned road, is Cresco, the point of departure for Canadensis, four miles distant. At that point there are five fine trout streams, also tributary to Broadhead's Creek. Good accommodations can be had at Canadensis.

Near Fork's Station, next above Cresco, there are sereral fine streams, all of which have been repeatedly stocked within the past four or five years by the Pennisylvania State Fishery Commission, and afford good fishing with either fly or bait.

Anglers who have more time at command, can take the New York and Erie road from New York City to Port Jervis, and the streams entering the Delaware from Pike and Wayne connties. That road skirts the river from Port Jervis to Hancock, a distance of eighty miles or more.

Good tront fishing can be had in many streanis in New York and Pennsylvania, running into the Delaware. The Mongaup, a short distance above Port Jervis, is noted in that respect.

The Shohola and its upper tributaries in Pike county are also good waters. At Lackawaxen in Pike connty, the Delaware and Hudson road to Honesdale and beyond, crosses many good trout waters. Nearly all the creeks tributary to the upper Lackawaxen, are natural trout streams.

At Masthope on the Errie road beyond Lackawaxen, is Masthope Creek, in which excellent fishing can be had; also at Milanville, Calicoon Creek, at Calicoon Depot. Hancock at the junction of the East and West Branches of the Delaware, is the point of departure for many of the best fishing streams of Wayne and of Sullivan county, New York. In all those streams the trout takes the fly readily. They abound in fine pools that are comparatively clear of brush.

The best flies for Northeastern Pennsylvania, are the "Epting," the "Queen of the Waters," "Black Gnat," "White and Royal Coachman," "Cahill," "Beaverkill," "Red Hackel," "Imbrie," "Grizzly King," and "Montreal." 


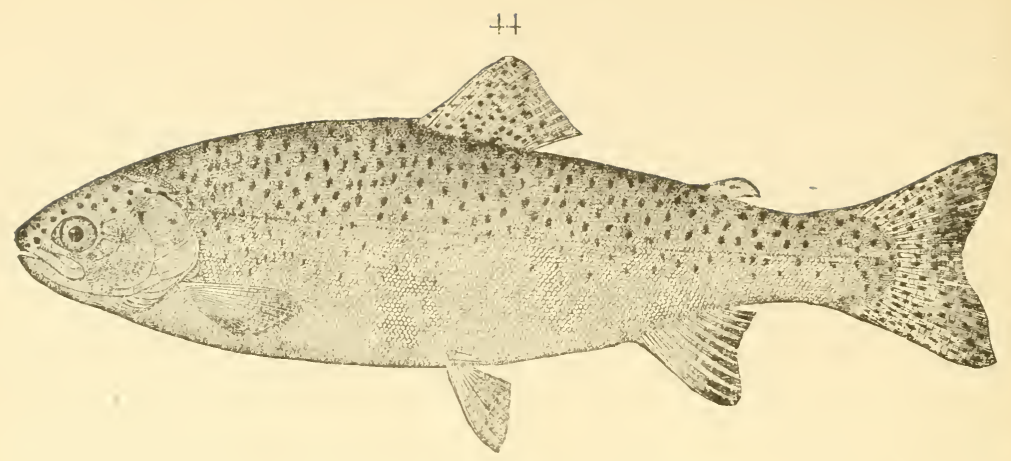

THE, RAINBOW TROUT.

(.Salmo iredeus.)

This beantiful fish, the introduction of which into Pennsylvania waters has been repeatedly attempted, and generally with but indifferent succesis, was brought hither from McCloud River, California, and in some localities is known as the "McCloud" Trout, as well as by various other names. The attempt to stock the lower streanis of the State with it was made, not because it was either the superior or the equal of our own Mountain Trout, but because it was clained for the Rainbow that it would live and thrive in streans of as high a temperature as $75^{\circ}$. Again its advocates urged in its favo:, that it was a much mo:e rapid grower than the Speckled Trout, as well as stronger and n110:e rigorous. As far as rapidity of growth is concernel, there is no dispute, but as to gameness and endurance, our sportsmen almost manimously repudiate the claim. That it needs as clear and as pure water as our native trout has been fully established, but though placed in our best streans, it has failed to realize in full, the expectations formed in regard to it. A serious objection to it is, that it spawns about the time when the open season for Brook Trout commences.

It is hardy, and bears handling and transportatio: well, but is eridently not adapted to our streams, though it is said that some very fine specimens have been taken in several of the waters of Cumberland county. 


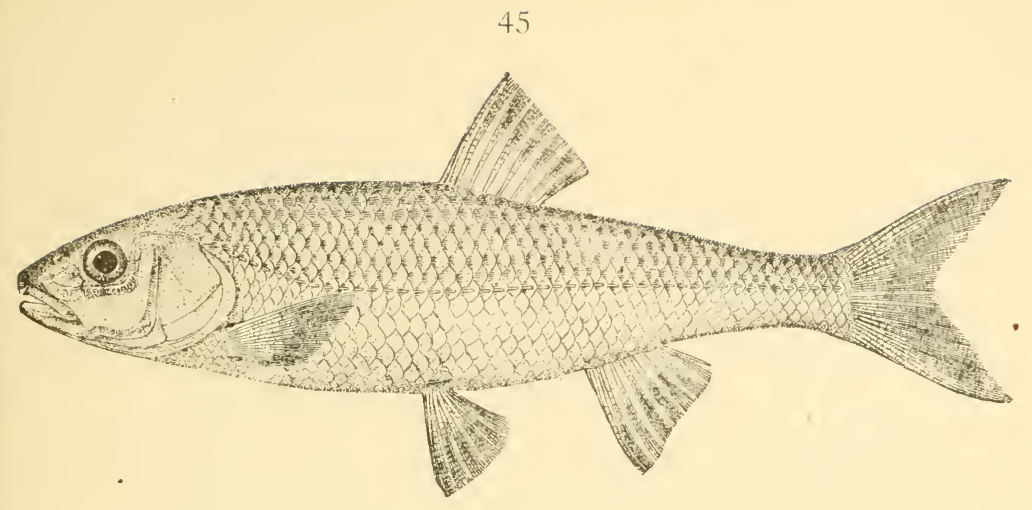

THE CHUB OR FALL FISH.

\section{(Leucosomus rhotheus.)}

Anong what are known as the bold-biters, there are few that excel in that respect the Chub or Fall fish. This fish is not regarded with much faror by trout anglers, for the reason that it is exceedingly aggressive, very voracions, rises readily to a fly, a worm, or in fact aln1ost anything in the form of a live lure. But for all that, there are a great many who hold it in high esteem for its dashing, gamey qualities, though its powers of endurance are of the limited order and its edible qualities not of the best.

\section{HaUnTS OF THE CHUB.}

The Chub is found in most of the creeks in the vicinity of Philadelphia. It abounds in the Brandywine, Perkiomen and many of the smaller streans, and was formerly quite abundant in those which were once noted for their trout, but which favorite of the angler has entirely disappeared from them. Other tributaries of the Schnylkill contain them. They are perhaps more plentiful in the several large tributaries of the Delaware above the Water Gap than in any other part of Eastern Pennsylvania, and are frequently taken in the Neshaminy and Pennypack. 
IVHEN AND HOW TO FISH FOR THEMI.

The best time for taking Fall fish is in the fall of the year, when they are in the finest condition. A grasshopper is a deadly lure for them, as is the large white grub worm, to be found in old stumps and decaying logs; though they are not apt to refuse a worm a eren a bit of dongh bait or cheese, and if the right-colored fly is offered-one with a big red body-the offer is very frequently accepted, and with a rim that often leads the angler to inagine he has looked a trout instead of a chub. It is a shy fish, exceedingly cleanly in appearance, being silvery white; graceful in shape, strong in morement, quick as a flash in biting, but not the best for the table. The size raries from twelve to eighteen inches, though still larger have been taken.

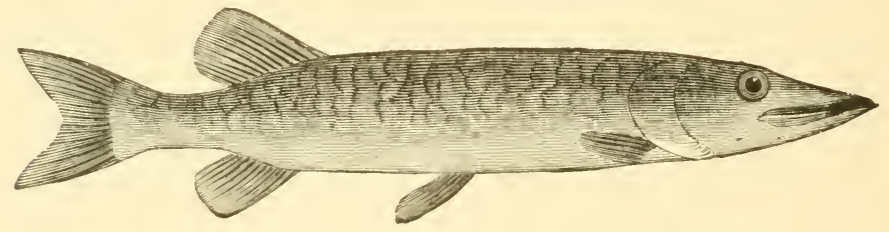

THE PIKE.

\section{(Esox recticulatus)}

The term, "Pickerel," is appliced to all fish of the Pike family, but as we are dealing with only "near by" fishes, it nill not be necessary to refer to those larger members of this interesting genus, as the Great Lake Pickerel, the Muscalonge, the Great Blue Pike and others: but confine our remarks to the "Pond" or Common Pike, which is found in most of the fresh waters of the Eastern slope of the Alleghanies, and to the Chain Pickerel.

\section{'THE PIKE'S GOOD QUALITIES.}

It is hardly necessary to describe this well-known fish. For table purposes, if from one to two pounds in weight, it is well 
esteemed, though there are better fish. One of the Pike's special recommendations, and a very important one, is the fact that it may be taken pretty much all the year round, in midwinter as well as in midsummer. Another is, that it is almost onnipresent in our streams and ponds; in the former, where lily pads prevail to considerable extent, and in almost any of the latter. There are many ponds in New Jersey within easy reach of Philadelphia where fairly good sport can be had at almost any time of the year. In the large pond at May's Landing, on the West Jersey Road; at Millville, Spring Mills, Atsion, Lake Hopatkong, in Northern Jersey, and in almost any of the many large ponds in that State, the angler, if properly equipped with tackle, and tolerably familiar with the use of it, may reasonably calculate upon good catches. Some of the branches of Forked River, N. J., are noted for the size, number and quality of the Pike taken in them.

\section{Methods of Pike Fisming, Bait, Eitc.}

The two principal methods of taking Pike are, with live bait and with the spoon or "'spinner ;" the live bait and the spoon to be adapted to the size of the general run of the fish in the water to be fished. A three-inch minnow will answer where the fish arerage from three-quarters to a pound and a half, and larger ones where fish of larger size abound. Sometimes a strip of pork, cut somewhat in fish-shape, will be taken as readily as the ninnow, and thus becomes a good substitute when roach or chub are not procurable.

Trolling from a boat or from the bank are the usual methods of fishing for Pike; the latter, of course when practicable, being always given the preference by the angler. The Pike takes the lure most readily on a cloudy day, from early morning until nine or ten o'clock, and from four o'closk in the afternoon until dark; though at times it will bite pretty much all day.

As most of the Jersey pond; are large, and bordered either 
with swamps or bushes, it is always wel1--in fact almost ind spensable-to liave a boat, and for comfort's salie as well as for the sake of success, some one to row who is familiar with the hannts of the fish. Such persons are usually found in the vicinity of the arger ponds.

\section{THE CHAIN PICKERIEL.}

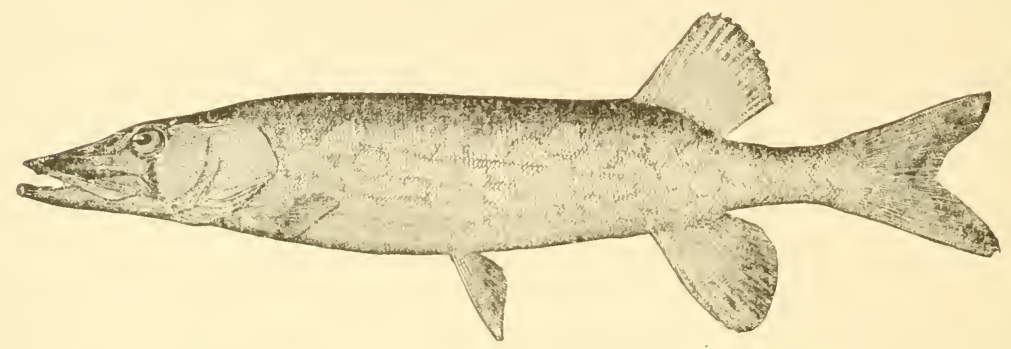

This is another member of the Pike fanily, not as abundant as the Common Pike, but attains a larger size, and is found in grassy creeks, where the water is clear, and in ponds usually well supplied with fresh water. Its flesh, instead of being yellowish, as that of the small pike, is pure white and of excellent flavor. It is very like the Common Pike in shape and habits, though more slender and graceful, but, as is shown in the illustration, its sides are so distinctly marked as to render it easy to distinguish between them.

It is predacious in the fullest sense of that word. feeding indiscriminately on nearly all other kincls of fislies, frogs, nice, rats, or almost any living thing that cones in its way, not excepting its own species. The Pickerel, when it attains a weight of three or four pounds and upwards, can be aptly compared to the blue-fish in roracity, and is fully the equal of that devastator of the finny tribes of the sea, in quickness of motion and in certainty of aim. It has been compared to a tiger in its spring, seemingly accurately measuring its distance and then rushing towards its rictin with 
almost lightning speed, rarely missing, and devouring its catch at a single swallow, unless too large for its throat capacity.

The Pickerel is fished for pretty much in the same manner as the Pike, with this exception, that stronger tackle is required. A popular method of taking them is what is called "skittering," which means "jerking or drawing the bait along the top of the water.' In Florida, where it is much practiced for Black Bass, it is called "bobbing." 'The tackle consists of a long flexible pole, with a short line, to which a strong spoon is attached. Thus equipped, let the boatman row along the margin of the lily pads, skittering the lure on the surface.

Trolling is another method, and quite a farorite one when the water area is large. Strong tackle, of course, is required, and the spoon or live bait will generally prove attractive.

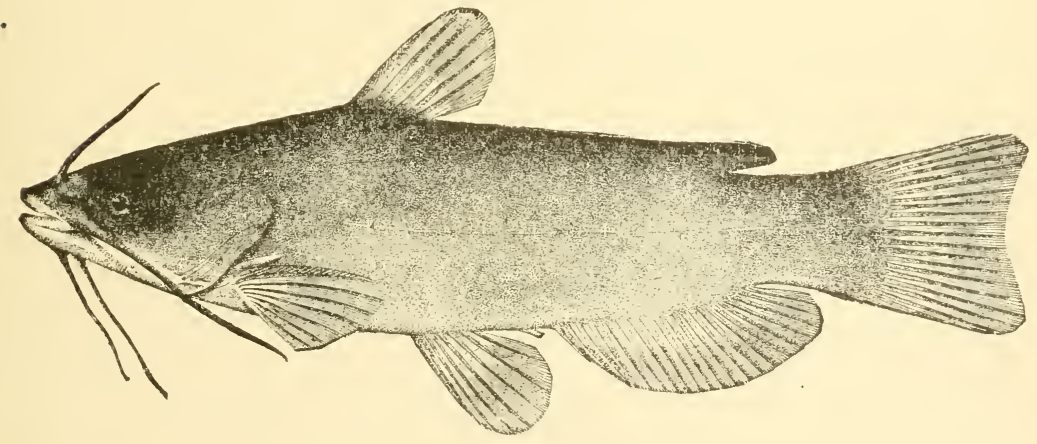

THE CA'TFISH.

(Silurida.)

No doubt some of those who are known, or, would like to be known as scientific "anglers" - not fishermen-will laugh, or pretend to do so, when they read the caption of this article, deeming-as at least some of them profess to do-the catfish entirely 
beyond the pale of true angling. But if we are to take so good an authority as the veteran Thaddeus Norris on that subject, we will find that " the true angler is thoroughly imbued with the spirit of gentle old Isaak. He has 110 affectation, and when a fly-cast is not to be had, can find amusement in catching Sunfish or Roach, and does not despise the sport of any humbler brother of the angle. *

* * * * A true angler is generally a modest man; unobtrusively communicative when he can impart a new idea; and is even ready to let a pretentious tyro have his say, and goodnaturedly (as if merely suggesting how it should be done) repairs his tackle and gets him out of a scrape." With sucl authority to back us, we shall proceed to say a word or two about the despised catfish.

\section{OMNIPRESENT, OMNIVOROTS AND TOOTHSOME.}

There are catfish and catfish, and they are nearly as ommipresent in fresh waters as they are ommivorous, for almost anything is acceptable to them, whether it be a crust of bread, cheese bait, sturgeon roe, worm, liver, or soft crab. The "near-by" angler will have to do with two varieties, the Yellow and the White Catty.

The former is the most abundant and is found at nearly all seasons in ponds, ditches, sluices and meadow ditches. It is not what may be termed a cleanly fish. It is a ravenous feeder, but not an eager biter. Haring an unusually large mouth and leathery jaws, when once hooked, its capture is certain. As to its edible qualities, they are not to be highly commended, though there are other fish that are no better.

The latter, known as the IIhite or Salt Water Catfish, is much the better of the two; better for gameness and decidedly better for the table. It is a free biter, and not specially fastidious as to bait. As with the entire catfish tribe, it generally prefers quantity to quality. It is an admirable fish for the pan, and as most Philadelphians are aware, is regarded with so much favor, 
that "catfish and waffle" suppers at the Falls of the Schuylkill, have been and still are regarded as treats of the highest order, fairly rivaling the "planked shad " dinners at Gloucester.

The White or Salt Water Catfish is to be found in nearly all the streams within easy reach of Philadelphia, except where the water is swift, and from early spring until late fall, when it returns to brackish or salt water, rennaining there during the winter. It is found at many places along the Delaware and its Pennsylvania and Jersey tributaries. Light tackle and small hooks will answer for either variety, with sturgeon roe, earth worms or raw liver for bait. Catfish may be taken at any time, and are at their best during the cool months, but bite most freely in summer.

Those who undertake to handle catfish, should exercise a great deal of caution, as it is one of the kind that always takes full loold of bait and hook, and whose jaws are so leathery and tough, that when the hook is fairly embedded in them, it is difficult of extraction. It therefore becomes necessary to handle it with the utmost care. As its sharp pointed stiff spines are always erect, there is danger of wounding, and those who have experienced the sting of a catfish need not be told that it is exceedingly painful, and has been known to produce fatal results. 'This is advice for novices.

\section{THE SHAD. (Alosa prastabilis.)}

Although Shad are found in such abundance along the entire coast of the United States as to give them a commercial value almost equal to that of any other fish, comparatively little is known of them, beyond the fact that they make their appearance in the Delaware early in the spring - the time of their arrival being influenced by the temperature of the water-and that the object is to reach the upper waters of the river for the purpose of spawning. That process accomplished, they turn their heads seaward, and if 
permitted, return to salt water, remaining there until the following spring. What becomes of them during the winter, the most careful study of their habits has failed to reveal. All that is known of them is that they come in the spring and spawn; the young are hatched, and in the fall they descend the river and find retreats, thus far, beyond human ken.

But what have we to do with Sliad in this book on angling? Only this, that they can sometimes be tempted to rise to a dexteronsly cast-fly, and in a few instances have been known to take a small bait. The capture of a shad with hook and line is therefore to be regarded as a notable achierement, but those who desire to bring home well filled creels are advised not to select the shad as the subject for their efforts, though of its table qualities nothing need be said. While bony to an aggravating degree, the flavor of the shad when properly cooked-planked or broiled for instanceis simply unsurpassed.

Thaddens Norris chronicles the fact, that lie was once fortunate enough to hook three in succession, when fishing for perch witl a bright little minnow below Fairmount dam, and secured two.

\section{THE ROACH}

Here we have another fisli, upon which the scientific angler is very apt to look witl contenupt; but there is that to be said in faror of the Roach, which cannot be said of any other fish in nearby waters-except the Pike-that it will take a bait on almost any bright, sunshiny, warm day during the entire winter. It is smiall but beautiful, with the tiniest of mouths, and yet an eager though cautious biter. The lightest kind of tackle is best-a rery thin line, a single gut snood, armed with several hooks as swall as No. I I Kirby ; a very light float, and just enlough of a sinker to carry down the line. The more delicate the ro1, the more suitable for Roach fishing. The Roach is found at Red Bank, on the Delaware, and around the wharves along the Camden side of the river; in Cooper's and Neshaminy creeks, and in kindred places. 
ROACH BAIT.

Varying from six to ten inches in length, quite agreeable sport can be had with them during the warm days of winter. Bait with dough paste, the bait being only large enough to cover the point of the hook. Fish near the bottom, and it may be, that two or three hooks placed at intervals of six or eight inches, according to the snoods. can be used to advantage. The biting is so nearly imperceptible as to escape the notice of any but an expert, a fact which renders Roach fishing the more interesting. As a table fish, it does not rank with the best, but will serve to rary the daily diet somewhat.

\section{THE GERIAN CARP. \\ (Cyprinida.)}

As far as we have knowledge, the German Carp is the only edible fish erer successfully introduced into American waters from foreign conntries. The history of its acclimation is interesting, as well as encouraging, and the more so, in that the "near-by" fresh waters have so largely profited by its introduction. The encouragement to be drawn from this fact is, that having been successful in adding one raluable food fish to our native list, there is a possibility at least that others equally well adapted to our waters will be found, and like the Carp, become profitable members of our many but still too few food-fish families.

\section{When INTROdUCEd into THE UNited States.}

It is only about twelve years ago, 1877 , that Mr. Rudolph Hessel, who, at that time, was connected with the United States Fishery Conmission, brought to this country from Bremen, three hundred and forty-five German Carp. They were taken charge of by Professor Spencer Baird, the then efficient head of the Commission, and under his capable direction, arrangements for artificial 
propagation were immediately made. In addition to that gentleman's theoretical knowledge of the methods of propagation and of the prolificness of the Carp in German waters, he very soon ascertained by practical experiment, that a valuable acquisition had been made.

\section{INAEDIATF, DEMANISS FOR THEM.}

Those strangers were rapidly propagated, and as freely distributed through the conntry as the supply adnitted. No sooner were their leading characteristics made known, than there sprung up a great demand for them. The readiness with which they could be propagated, their prolificness, hardiness, rapid growth, adaptation to American waters, and their fairly good edible qualities, commended them to farorable comsideration.

\section{UTILIZATION OF IVASTE IAND.}

Farmers learning that swamps and bogs, not available for arable purposes, and unsightly as well as unlealthy, could, at a small outlay of money and labor, be converted into pleasant-looking ponds, in which the German Carp would live and rapidly multiply, became eagerly desirous of securing them. Thousands of acres of previously waste lands were thus utilized, and where, as is usually the case, there was a small stream of water, the owners had the satisfaction of not only seeing those waste places converted into profitable use in the shape of fruitful fish-ponds, but of securing, in addition, a supply of ice from them for summer use.

\section{GENERAL ADAPTATION TO AMERICAN IVATERS.}

With the first introduction of the German Carp, there was a generally prevalent impression that they were adapted to pond-life only, and that they were by nature opposed to streams, save those of the most sluggish kind; but later experience has entirely dissipated that idea. 
It was only a few years after the first distribution by the United States Fish Commission at Washington, that the capture of strange-looking fish in a gill seine was made in the Delaware, and shortly thereafter a number were taken with hook and line in the Schuylkill, where a few had been placed under the anspices of the Fairmount Park Conmissioners. Some escaped from orerflowed carp-ponds, finding their way into the nearest strean1s, where they speedily multiplied, m11til, it can be said of them to-day, that in the few intervening years they have-with the exception of the shad - becone the most plentiful of the larger sized fish in our rivers.

\section{WILL TAKE THE BAIT.}

Another erroneous impression was, that the German Carp would not take the bait except on rare occasions. It soon began to be practically demonstrated that such was not the case, it being found that they conld not only be tempted with certain kinds of bait, but during the greater part of the year-the exceptional months being the wintry ones, when, if the weather is very cold, they retire to the deepest waters, where there is mud botton, remaining there until the recurrence of more genial temperature.

River and creek anglers were frequently astonished to find themselves contending with large, active and rather gamey fish, upon landing which, they discorered that they had been dealing with what were to them entire strangers, that had to be taken to some ichthyological expert for identification. The Carp increased in pond and stream with marvellous rapidity.

\section{PROLIFICNESS.}

An idea of the Carp's prolificness will be gleaned from the fact that a female of four or five pounds contains, when ready for spawning, from 400,000 to 500,000 eggs. If but ten per cent. of that vast number are hatched and survive, it is not difficult to understand why those comparative strangers have already become so numerous. 
In riew of such facts, the introduction of this fish into American waters is to be regarded as a raluable boon. Large as were the anticipations of those through whose agency they were brought here and distributed, they have been greatly exceeded by the practical results, and it is rery evident that most of the "near-by" rivers have been sufficiently stocked with them to warrant confidence in the belief that they will become so abundant as to have a commercial as well as a sporting value, and that in a few years they will be found side by side on the fish stalls with the striped bass, perch, pike and other well known varieties.

\section{A PROYIDER FOR G.AMF Fishes.}

There is one feature connected with the carp that entitles it to farorable consideration. Not being predacious, and yet a wonderful propagator of its species, its young will supply food for the Black Bass, Striped Bass, Wall-Eye Pike and other kinds that subsist entirely on animal food, mainly, upon live minnows.

The Carp's most marked characteristics are hardiness, fecundity, extraordinary rapidity of growth, adaptation to pure waters that are not too rapid, and last but not least, a readiness to take the bait.

\section{HABITATS.}

There are as yet no well defined Carp habitats. Large numbers of very fine ones have been caught with worm bait at the mouth of Woodbury Creek, and also in other Jersey tributaries of the Delaware; and in the Neshaminy and Pennypack. For several years they have been taken of fine size in almost any pool between Fairmount dam and as far northward as the Black Bass frequent. They have also been killed in the Susquehanna, which is a most farorable indication.

It is yet too soon to determine their habits, as far as biting is concerned. A gentleman of Philadelphia who has perhaps taken 
more of then up to this time than any other, has been nuable to determine whether their feeding times are or are not influenced by the tides. They appear to bite as well on flood as on ebb, and he thinks they more in schools, picking up their food wherever they chance to find it.

\section{BAIT AND TACKLE.}

The most taking bait thus far found, lias been the common red worm, obtained near manure heaps, grains of wheat, a green pea, bread crumb paste, a bit of macaroni partially boiled in plain water, are all acceptable. Iight Bass tackle is best, with a sinker just heary enough to keep the line on the bottom, with the baited look on the ground. A gut leader is always preferable, as the carp is a wary fish. The look should be very small, the bait ditto, as the mouth is of the most limited dimensions. It is easily frightened, therefore, the more profound the quiet the greater the likelihood of success. When a bite is perceived, do not be in a hurry, as the fish will begin to move when it has fairly mouthed the bait. When it does more, then strike.

The close season is from the Ist of May until the Ist of September, the law reading thus: "It shall not be lawful to catch, kill, take or remove in any manner from any public lake, stream or spring, any fish of any size or age of the species known as the 'Cerman Carp,' during May, June, July, or August of any year." 'There is 110 close season for Carp in New Jersey.

\section{THREE VARIETIES.}

There are three distinct varieties of the German Carp, all of which have representatives in Pennsyivania and New Jersey waters. They are respectively known as the "Scale Carp," the "Leather Carp," and the "Mirror" Carp. 


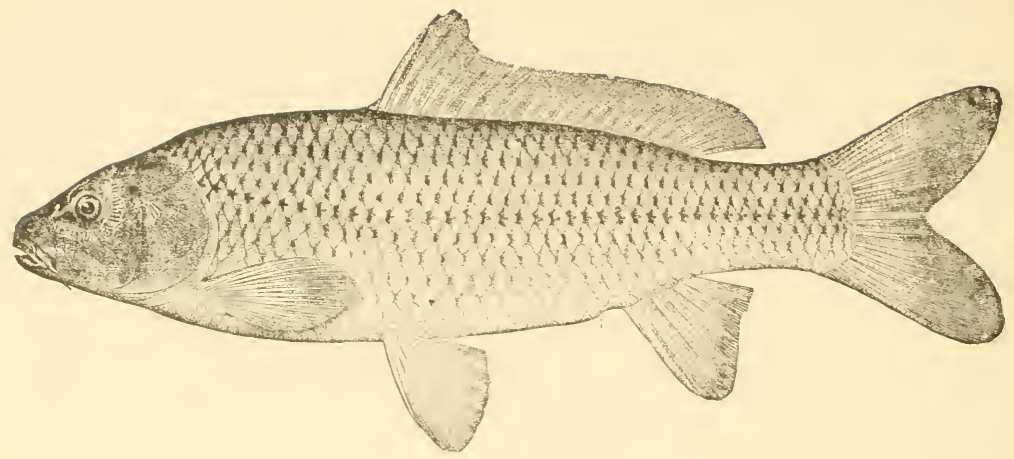

\section{THE ASIATIC OR SCALE CARP.}

\section{(Cuprinus carpio communis.)}

The first named, the "Scale Carp," is said to be the original species improved, though it is not stated what the original species looked like. It has regularly, concentrically arranged scales, as is shown in the illustration. It is a handsome fish, and whether for gameness or the table, has thus far the preference over the other varieties. Whether it is less prolific or whether there has been a sparser planting of them, has not yet been determined, but thus far, the scale species is not nearly as plentiful as the "leather" or " minror."

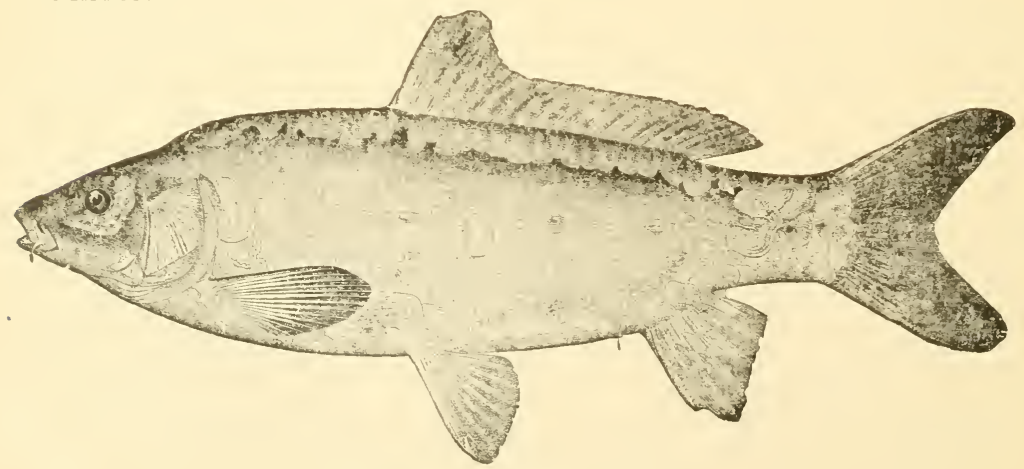

THE LEATHER CARP. 


\section{THE LEATHER CARP.}

\section{(Crprinis carpio coriaceus, size mudus.)}

The "Leather" Carp has the marked peculiarity of laving on its back a single row of scales-sometimes none at all, while the other parts of its body are corered with a soft, thick skin, velvety to the touch, and which becomes slimy when handled.

\section{KING OR MIRROR CARP.}

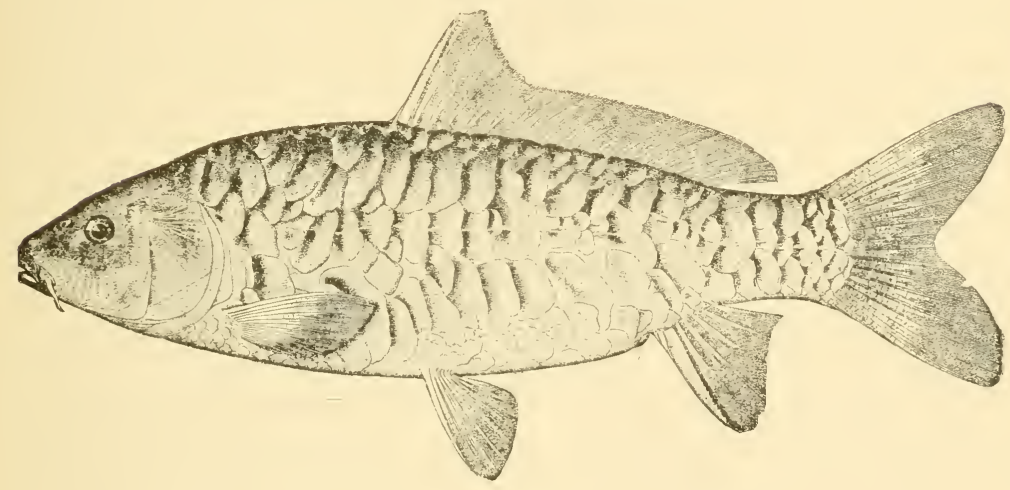

(Cyprinus carpo specularis.)

The third is the King or "Mirror" Carp, so-called from the very large and irregularly placed scales which run along the body in three or four rows, leaving the rest of the body bare.

Each of the three has its admirers, hence it is difficult to determine which is really entitled to general supremacy. All of them are beautiful, and are so strongly built and so well formed as to readily explain their gamey qualities. Another characteristic is the unusual quantity of blood. When being cleaned, this becomes very apparent, and suggests that if they were bled-as all fish should be immediately after capture, the quality of the flesh 
would be materially improved. They are also exceedingly tenacions of life. Instances have come under the writer's observation , in which, after being out of the water for three or four hours, they beconne as lively as ever when restored to their native element.

No apology is offered for the amount of space given to these fish. They are to be regarded as most valuable additions to our list of food fishes, as they are the only one of trans-Atlantic origin ever made. Their remarkable adaptation to American waters has already been practically demonstrated as well as their enormous capacities for reproduction. In many parts of Europe they are regarded with much faror for table purposes, and there is room for the belief that when they have lived in our fresh waters for some time, the quality of their flesh will be materially improved, at least, such is the opinion of those who have given then careful study.

Having thus, in a familiar way, given the habitats and nost marked characteristics of the " near-by " fresh water edible fishes, it only renains to be said, that as "whaterer is worth cloing at all is worth doing well," so the person who desires to indulge in either " "near-by " or " far off" fresh water fishing, should enter ipon that kind of recreation properly equipped.

Assuming that such outings will be repeated at least several times during the summer and fall, a moderate outfit will be found essential to confort and success. Such an ontfit can be expensive or inexpensive according to the taste and excliequer of the purchaser. A novice should begin with what is known as a light perch or bass rod, muless he aspires to the taking of the large striped bass at the noutl of the Susquelianna, when a heavier will be required. Next, a good, smooth-rumning, liundred yard reel, a nine-tliread Cuttyhunk cable-laid or braided hempen or silk line; a small assortment of hooks of different sizes, which may comprise Sproat, Limerick, Kirby, Chestertown or any other of the standard varieties. The hooks should be snooded, and single gut will be found sufficient for any but the heavier fishing. A few two and 
three foot leaders may come into play, also a few light dipsies and split shot, and one or two neat floats. If bass or trout fishing is contemplated, a pair of wading pants, a landing net, a basket creel, and a reel for drying lines will be needed. Such an equipment can be made to cost a great deal of money, or it can be purchased at an outlay within the means of almost any one, and will answer the purpose as well as the more expensive, besides being adapted for the lighter kinds of sea fishing, which will be considered in subsequent chapters. But whatever materials comprise the outfit, let them be of good quality. There is no economy in buying cheap tackle.

\section{"NEAR-BY"}

\section{SALT IVATER FISHING.}

Although the sea-or any salt water-is not less than fron fifty to serenty-five miles from Philadelplia, so many are the lines of communication with it, so rapid the transit and so reasonable the fare, that places even more than a hundred miles away, may properly be classed under the head of "near-by" fishing localities. The nearest points, as Atlantic City, Somers Point, and Ocean City, can be reached in from ninety to an hundred ninutes, the first naned by three roads, the latter by one-the West Jersey. By taking one of the earliest morning trains, either of the places named is reached by it in time to afford the angler, who has but a single day for a fishing outing, six or eight hours sport and ample time to secure a home passage by the latest train.

There are other points as Sea Isle City, Townsend's Inlet, Avalon, Anglesea, and Cape May southward, and the many places on Barnegat Bay as 'Tuckerton, Beach Haren, Harvey's Cedars, Barnegat City, Waretown, Forked River, Toms River and Sea- 
side Park, which can be reached by the latest train in the afternoon-learing generally about four o'clock-and giving a whole day's fishing next day and a returning train the erening. 'That, to be sure, involves the additional expense of a night's hotel accommodation, but connensation is found in the facts that you have a longer time for fishing, and the best part of the day-the morning-for its enjoyment.

There are many who can take a day's fishing on legal holidays only, as Decoration Day, Fourth of July and Labor Daywhen banks, stores and public offices are closed-therefore, whether it rains or shines, whether the tides suit or otherwise, haring no choice in the matter, they must take things as they find themfarorable or unfavorable.

There are others who are not thus tied down by business, who can go and cone at their own pleasure, and who therefore can arrange for a fishing trip to the seashore and thus

\section{Avoin DisappoINTMENTS.}

At nearly all prominent fishing localities, are persons who are willing to give the needed information in regard to tides, bait, boats boatmen, etc. A line addressed to such persons will generally bring a prompt response, if the request is accompanied with a postage stamp for a reply. In lien of a better resource, apply to the postmaster, who will either himself answer, or hand you a note to some one who will. Being thus informed, subsequent arrangements can be intelligently made, and you will be well repaid for your trouble.

You may have tide, boatmen, bait, fish and weather just right on any legal holiday, or on any other day you may select for your outing; the fish may be plentiful and in a biting mood, and you may have a good time, and then again, you may not. It is, therefore, alway's adrisable - if sport is your object and you can do itto make your arrangements some days in advance. 


\section{A SALT I'ATER Fisherman's OUTFit.}

The outfit needful for angling in salt waters, although required to be stronger and stouter-as far as tackle is concerned-than that used for fresh water fishing, is much more simple and less expensive. As most sea-fishing is done from boats, there is not only no necessity for long rods, but an almost positive requirenent that the extreme length shall not exceed eight and a half feet-seven and a half is better. The lumbering, heavy rod-once called the standard-should be wholly discarded, and the much lighter, more easily handled and equally effective one purchased. Such a rod can be had of excellent quality for from four to five dollars at any of the tackle stores. If you can afford the outlay, always carry two, for the sea is big, and there's no telling what kind of a fish will take your bait. Accidents, you know, will happen, and it is exceedingly provoking to find ones-self at sea, with a broken rod, and the fish biting.

\section{SEA LINES AND REELS.}

There is 110 better line for sea-fishing than the cable-laid hempen, Cuttyhunck or its equivalent. A nine-thread is strong enough for any ordinary fishing, and is to be preferred, as the tide friction is not nearly as great as when a heavier one is used, consequently, a lighter dipsey will answer. It will not be aniss, however, to have a heavier one in reserve.

A good reel is indispensable to comfortable and successful seafishing. One that will not corrode is to be preferred; but whether of brass, nickel, German-silver or rubber, be sure to get one that runs smoothly. If, in making your selection, you come across one that has a halting, hesitating, harsh morement, incontinently reject it, even though made of solid silver. You can suit yourself as to price, as reels are made at from one dollar to fifty, with all intermediate grades. From five to ten dollars will purcliase one of excellent quality, which should be of the capacity of about one hundred yards of line. 


\section{SNOODS AND LEADERS.}

Gut snoods and leaders are always preferable to twine. They are a little more costly but the additional expense is not heary. Some salt water anglers think two or three foot leaders indispensable, others reject them entirely, preferring the simple long snood, looped on to the line. Tightly twisted snoods are not the best, as they are apt to be affected by the salt water and unrarel unpleasantly.

\section{HoOks.}

Of hooks there should always be carried a good assortment, avoiding however, the too frequent error of buying the largest sizes. A few years ago the impression prevailed that large hooks were absolutely essential for sea fishing, but, as light, short rods have superseded the long heary ones, so the smaller hooks have, to a considerable extent, taken the place of the larger. In point of fact, the cumbrous tackle of years ago has been pretty much laid aside, greatly to the enlancement of fishermen's confort.

As there is 110 certainty as to the depth of the water in which sea-fishing is to be done, and as the tides vary in force, it is well to provide an assortment of clipsies, rarying in weight from half an onnce to four ounces. They are made of many shapes and are known as swivel, screw, hollow-ball, etc. The hollow-ball is used mainly for sheep's-heading, the others for almost any kinds of sea-fishing.

A Few Other Eissextials.

A pair of cheap orerhatuls, a landing net, a pair of plyers, a good sized, sharp clasp knife, a fine file, a bit of sand paper, and a small sized leather caba to contain the tackle. A drying reel, for drying lines that have been wetted with salt water, should constitute part of the ontfit. It costs only fifty cents, and will pay for itself twice orer every season. 
There are those who cannot be persuaded to abandon the oldtine, heary hand-line in sea-fishing. That kind of tackle is one of the relics of a past age. It is cumbrons, tiresome to handle, uncertain and frequently most annoying. If you intend becoming a professional or even an amateur fisherman, make up your mind to begin with the rod and reel, and cast the hand-line to the "owls and bats." Ion can use the rod and reel in any water, where a hand-line can be, and in many places where the latter is not available. Other things being equal, you will catch more fish, and your sport will be ten times greater. The rod is not of course recommended for cod fishing, though it might be made available there.

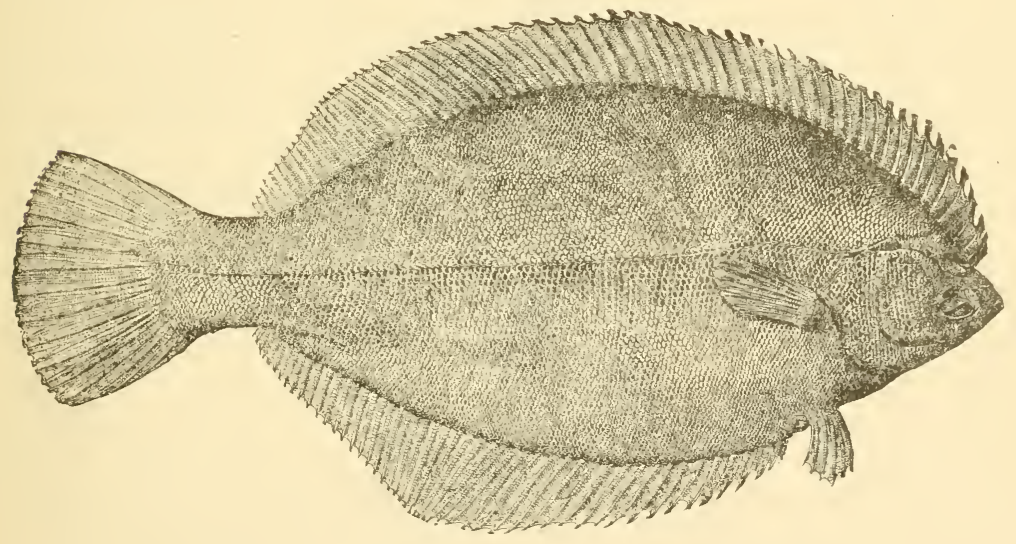

THE FLOUNDER.

\section{(Platessa vulgaris.)}

Although this singular fish has no title to the designation of "gamey," it has two virtues, which are of a highly redeeming character. The first is, it is the pioneer of the lure-taking sea fishes in the spring, and the last to leave in the fall. It is on hand, generally speaking, from the first of April until November, biting 
all the time, when opportunity is afforded it. It is a gentle nibbler, but sometimes takes rigorous hold, and if the hook is not too large to be swallowed, the catcin is sure. Naturally, from its peculiar shape, the Flounder feeds on the botton and 1nust be fished for there. Small hooks are required, and as to bait, while it no doubt has its preferences it will take almost any that is offered-a bit of clam, or sand wornu, crab or 1111sisel, alike appearing to be relished.

\section{Secont ReDenuixg ViRTeF.}

The Flounder's second redeeming rirtue is its excellent table quality. Although not the best fish the sea produces, it is far from being the poorest, in a word, when properly cooked, it is fit for any table.

As to the Flounder's habitat, it may be said to be everywhere. Barnegat Bay abounds with then in early spring, especially in the vicinity of Forked River, at Harvey's Cedars, Beach Haren, and indeed anywheres in the Bay, and in greater or less abundance at almo.it any point along the Jersey coast.

\section{THE; BLACK FISH.}

\section{(Tautoga onitis.)}

Anong the earliest sea-biting fishes is the Tautog or Black Fish, so called. Its arrival is pretty nearly contemporaneous with that of the Flonnder, and like that early bird, it takes the bait at once. It is a free biter, and when taken of a pound weight and upwards, may be called gamey, as it is powerfully finned and very strongly built.

The Tautog loves rock-strewn tideways, wrecks, old wharves, and piers, where small mollusks are to be found. It also frequents the sedgy and soddy edges of meadows, where the water is deep and the tide not too strong, and can be taken from early April until the middle of Octolver. 
The tackle required is pretty mucl the same as that for weakfish in point of strength, but the hooks should be snaller and of stronger wire. The Chestertown is admirably adapted for Tautog fishing, though for that 1natter, any of the stronger standard kinds will answer. Fasten the snood so that when the line is perpendicular, the hook will be somewhat less than a foot fron the bottom. Hard clan, sand worns and fiddlers are greatly relished.

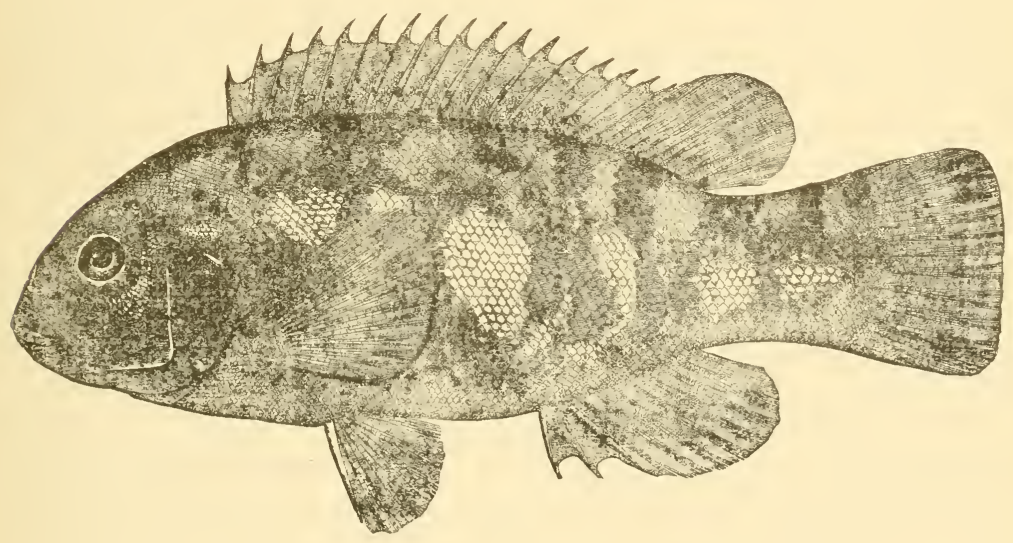

The Brack Fish.

In regard to its qualities, the Tautog lias few superiors. The flesh is white and firm, and if properly cooked, it is one of the most toothsome of salt-water fishes. It must not be confounded with the Sea Bass, which is frequently done, because, perliaps, that fish after it is dead, is much blacker in hue than the Tautog, which in respect of color, is singularly mis-named. The Tautog has a heavy coat of scales, that is not readily remored miless the fish is first dipped in strong rinegar. A better way is to skin it, which is easily done, and is considered preferable with a great many of the smaller thick-skinned fishes. 


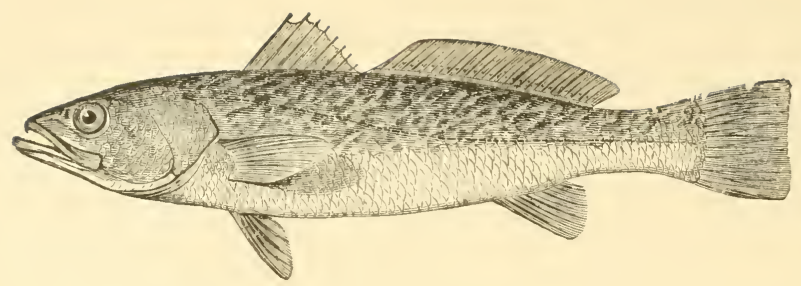

THE WEAK-FISH OR SQUE'TEAGUE.

(Cynosion regalis.)

This beantifu1 fish, which in point of rich coloring has no superior in our coast waters, is variously known as the "weakfish," "blute fish," "sea trout," "wheatfish" etc., but whence it derived its most commonly applied name, "weakfish, " has never been satisfactorily determined. It is one of the gamest of our seafishes, efualling in that respect the Striped Bass, but lacking that noble fish's powers of endnrance. It takes the bait with the same greedy avidity, and its first dashes are tremendous, if the hooked fish be of good size, say two or three pounds. The larger the fish the more powerful its struggles, and the more prolonged its contest for life.

\section{E.ARLY BITERS.}

A few years ago it was generally believed along the Jersey coast, that weak-fish would not take the bait until about the first of July, but that belief has been completely exploded by facts. For five years past the writer has canght them in large numbers in Cape May waters, early in May, though none but females, and they in gravid condition seened inclined to bite. As the season advances, they make their appearance all along the coast, the difference in time between their first arrival at the Cape and at Atlantic City or Barnegat Bay, being from two to three weeks. They remain during the summer and until the latter part of September, when they commence their southward migration in schools. They are then in their finest condition for the table and in their gamest 
moods. Immense quantities of them are taken at that time, the almost entire coast fron: Sandy Hook to Cape May being lined with yachts and other small craft filled with eager fishermen.

During the summer, the weak-fish are found in all the estr:aries in greater or less abundance, and at varions points in Delaware Bay on both sides, from Ship John Light to the Breakwater. Although there are certain stages of the tide when they feed most vigorously, they are very capricious, frequently biting freely at most mexpected places, tides and times.

\section{VARIOUS MeTHODS OF ANGLING FOR THEM.}

They are not strictly surface fish, nor yet what are known as bottom fish. In some localities in Barnegat Bay, especially on the flats, opposite Waretown and Forked River, they are most readily taken with a float and a light sinker, and with the hook within two or three feet of the surface. Those caught there, and in that way, are usually of swllall size. In Great Egg Harbor Bay the same style of rig will answer, but only on the flood tide, when the flats are well covered, and the water from six to ten feet deep. The fish there are of larger size than in Barnegat Bay. As a rule, the largest fish are not taken near the surface, though of course there are exceptions. The writer's experience has satisfied him, that the most effective tackle for deep water fishing-from fifteen to thirty feet and upwards - is a sufficiently heavy sinker to keep the line taut, and the lower bait on or very near the bottom. At a snell's length above the sinker, loop a single snell on to the line, and three or four feet farther up, a two or three foot leader, or a single-length gut snell. 'The lower hook should be smaller than the upper, as the chances are largely in faro: of capturing hake or king-fish while angling for weak-fish.

\section{WHEN THET BITE BeST.}

During the flood-tide, the waak-fish generally keep in the channel-ways, where they go in search of food; but when the tide 
begins to ebb, they are almost certain to seek the deeper water, where they remain until the next change of the tide again entices them to their feeding grounds. Fxperienced fishermen regard the latter lialf of the flood and the first of the ebh-tide as the best stages for successful fishing. They will take the bait readily at 11ight.

\section{BIG CATCH OR SPORT?}

When a big catch is desired and sport is only a secondary consideration, a con1paratively heary, short rod is needed-one that will bear the weight of a sinker sufficiently heary to carry the line and the bait quickly to the bottom, and also adnit of the rapid reeling in of the fish: but if real sport is the object, use a bass-bait-rod. from seren and a half to eight feet in length, a reel that will carry a liundred yards of the finest linen line and I o or 2 oo hooks of the make you prefer. A light sinker will answer. The large hooks, once considered indispensable, should he avoided.

\section{A TALT IINF.}

The sight of the weak-fish is said to be keener and sharper than that of any other estuary fish, hence the greater probability of a good catch when the water is not " thick, or "riley." It takes the bait with a rush, and the monnent the strike is felt, keep a tant line on your prize until it is safely landed. Do not permit an inch of loose or slack line, for the mouth of the weak-fish is large, and the sides of the jaws thin and tender, so that when the hook penetrates that part, as it is very apt to do, there is certain to be a large orifice, which, if the line is not kept tant, enables it to throw out the look and escape.

\section{TABLE QUALITIES.}

Although a small weak-fish has little or nothing to recommend it for table use, the larger ones are just the reverse. The 
meat is white, and that of the four and fire pounders, almost as flaky and well flavored as that of the salmon; but to have it in perfection, the weak-fish should be bled before it dies, and cooked soon after being canght.

As far as bait is concerned, soft or shedder crabs are always acceptable, indeed, may be regarded as the best, though at times a piece of clam, a black mussel, the throat-latch or eye of a brother weak-fish, or a three inch shiner, will prove equally attractive. In the spring of the year, shrimp bait is by all odds the best and for that matter, is good at any time if the water is clear.

For the earliest fishing on the Jersey coast, go to the Cafe May thoroughfares about the middle of May. For later fishing you will find them in almost any of the estuaries of the coast, and in great abundance at many points on both sides of the Delaware Bay, notably at Slaughter's Beach, on the West and at Ship John Light, Fortescue Beach, Bay Side, and on the "Shell beds" opposite Fishing Creek.

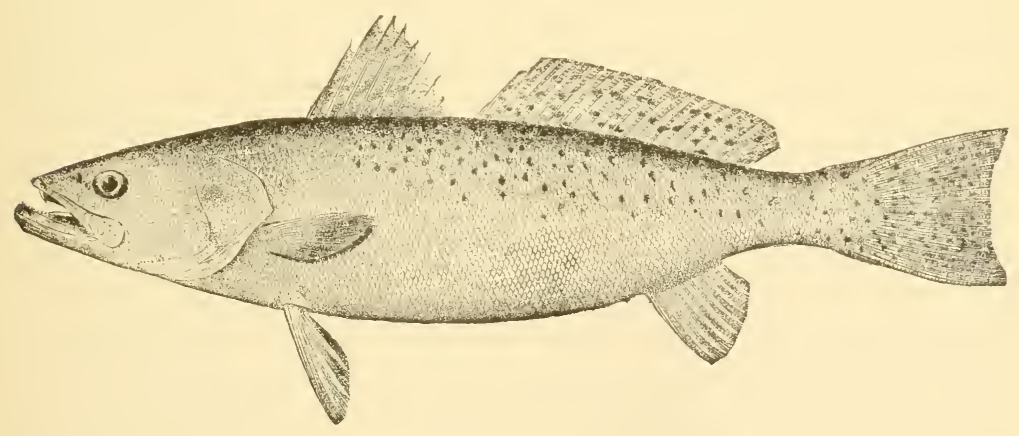

'THE SPO'T'TED SQUE'TEAGL'E.

This comparatively scarce fish in Northern waters, a member of the weak-fish family, is a native of the South, and is especially plentiful along the Carolina coast and on the Atlantic and Gulf coasts of Florida. It is in several respects better than its relative, 
the weak-fish, being not only as voracious a biter, but mucl more gamey, and with greater powers of endurance, while its table qualities are decidedly superior, the meat being white, firm, flaky, and weil flavored. It is besides a much better keeper.

It is to be regretted that so few of them risit the North. Those that are taken are generally of good size, weighing from two to five pounds. In the South, they are known as "Sea Trout," and are so abundant there as to have a large commercial value.

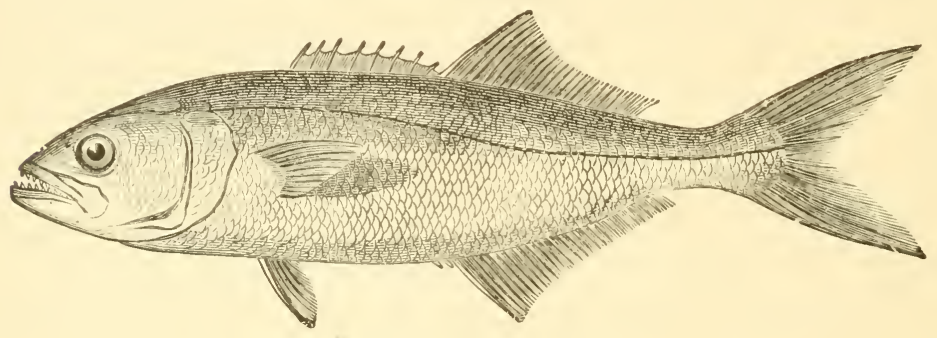

THE BLUE FISH

\section{(Temnodon Saltator.)}

"The pirate of the ocean" is one of the appropriate designations given the famous Blue-fish, a fish that has afforled as much enjoyment to those who are not particular as to the manner of fish capture, as perhaps, any other that srims. While it is one of the most unyielding of fighter: the usual method employed for killing it is not, in any sense, sportsmanlike. It requires 110 skill-the fish hooking itself. It is only a contest of strength between the person who holds the trolling line and the struggling fish at the other end of it. It is that simple fact, coupled with the exhilaration of the sailing, however, that gives blue-fishing its special charm in the estimation of so many. Any one-even the merest novice-who can stand the sea when a stiff breeze prevails, and whose hands can endure the friction of the trolling line, is just as likely to be successful as the most experienced angler. It is well that it is so, for while the love of fishing is innate, only the com- 
paratively few have the time and opportunity for indulging it, that are requisite to constitute them anglers in the true sense of that term. Hence, thousands find healthful and delightful recreation in trolling for the murderous blue-fish, not a few of then being of the weaker sex, who, ever on the alert for chances to place themselves on an equality with man kind, have discovered in that sort of recreation a wished-for opportunity, and rarely fail to improve it.

\section{MHEN THEY CONE.}

The appearance of the Blue-fish along the Jersey coast is regulated in a large degree by the temperature of the water, though it is suggested by those who have made it a matter of close study, that the time of their arrival is governed by that of the menhaden and other fish which constitute their farorite food. Be that as it nuay, they are sure to put in an appearance about the Ist of June, remaining nntil October, the larger ones not migrating until the latter part of the month.

\section{OUTFIT.}

Blue-fishing is such a simple process, that little can or need be said either in regard to the tackle, bait or style of fishing. The requisites are a stout cotton line some three hundred feet in length, and a squid of bright metal of such style as may suit the taste or caprice of the purchaser. The hands should be protected against the friction of the line by a pair of stout glores, woolen or leather, or a set of gum finger-stalls-the glores to be preferred. Trolling naturally suggests a sail boat and a spanking breeze, for without both, blue-fishing camnot be clone. Therefore, after having secured your line, squid and glores, your only care will be to find your boatman and the breeze.

\section{Oidd Fashioned Squids.}

Prior to the days when brilliant squids tecame faslinonable, a piece of wood, covered with dried eel-skin, and with a hook 
attached, was almost the only squid known, and it is said by those acquainted with blue-fishing twenty-five years ago, that fully as many were taken with that primitive lure as with the more highly finished and costly ones of to-day.

\section{ROI AND REEL, BLUE-FISHING.}

But trolling is not the only method of taking this formidable fish, nor is that method generally regarded as sportsmanlike. The other method, although not generally practiced, is one that taxes alike the tackle and the skill of the angler. A great deal has been said within a few years in regard to Tarpum fishing in the waters of Sonthern Florida. Men who have succeeded in capturing that king of fishes have rightly earned renown, and their names have been duly chronicled as being fairly entitled to a place on the scroll of fame, but notable as such achievements have been, they are scarcely more so than the taking and killing with rod and reel, a twelve or fifteen pound blue-fish, when on his way southward in October, in the full vigor of health and strength. Those who have tried conclusions with such, will readily agree that they are the gamest of the game, and with powers of endurance that are truly wonderful.

Stout tackle is of course required for the kind of angling alluded to, not so much in the rod as in the line and hook. An eighteen thread Cuttyhunk two hundred yards long, and a correspondingly large reel will answer the purpose, with a large, strong hook attached to piano wire. Withont this last precaution, you may as well not attempt the capture of the Blue-fish, for his jaws are so armed with formidable teeth of razor-like sharpness, that a line quadruple the size of that recommended, would be instantly severed if brought in contact with them.

\section{HOW THE ANGLING IS DONE.}

Thus equipped, the fisherman anchors his boat at some point near where the blue fish are in the habit of frequenting; and in 
order to keep his hook from sinking too deep, a float should be placed three or four feet above the bait. While an artificial baitas a minnow-will sometimes tempt a strike, something more edible will be found decidedly more effective in still fishing. A piece of fresh menhaden or other bright colored fish, is a sure bait.

Having thus prepared himself for the fray, the angler awaits the arrival of his intended victim. His patience may be sererely taxed, or he may be at once rewarded with a strike. When it does come, there will be a commotion, for no sooner does the blue-fish feel the prick of the hook, than he darts away at a rate that threatens to make instant wreck of tackle, but, as with all other fishes of his class, this one must be dealt with coolly and calmly. Give him line freely but judiciously, and if possible, keep it taut all the time. He may "run up" on you, and when he gains that "coign of vantage," he has a way of ridding himself of the hook not readily comprehended, but withal a fact. Therefore, keep a taut line, reeling him towards you whenever he manifests the slightest disposition to humor your inclinations in that respect. If - as he is almost certain to do-he goes with the tide when hooked, your labors become the more severe, but perseverance and good tackle handled with masterly skill, will ultimately win, and when you have landed your first big blue-fish, you will be likely to confess that you never before tackled one of his size, that struck more fiercely, ran with greater swiftness, pulled harder or fought longer or more bravely. Those who have taken the "Tailors" of the Chesapeake and of the estuaries of the Atlantic coast, can form an idea of the tremendous powers of the adult blue-fish. Tailors are the young blue-fish.

Perhaps no other fish common to American salt waters, possesses a greater anount of interest for the angler or the ichthyologist. The more "the wolf of the sea" is studied, the more interesting it becomes. Either always hungry or slaying for the mere love of it, the blue-fish is a fit representative of the Ishmaelite, whose hand was against everybody and everybody's against his. Built for strength and swiftness, armed with teeth of 


\section{6}

the most formidable character and stimulated by an appetite that appears to be insatiate, he roams the waters at will, carrying havoc and death with him wherever he goes. Professor Baird, in his well-known description of the blue-fish and its habits, says:"Such is the gluttony of this fish that when the stomach becomes full, the contents are disgorged and then again filled. ***** Going in large schools in pursuit of fish not much inferior to themselves in size, they move along like a pack of hungry wolves, destroying everything before them. Their trail is marked by fragments of fish and by the stain of blood in the sea, as, where the fish is too large to be swallowed entire, the hinder part will be bitten off and the anterior part allowed to float away or sink." And this destructive spirit is displayed by the younger fish, as fully as by the adults.

The authority just quoted, estimates the number of blue-fish captured during the season at not less than a million individuals; that as probably not one of the fish in a thousand of those existing in the sea is erer taken by man, therefore, there is a thousand million of them on the coast between New Jersey and Monomoy. An allowance of ten fish per day to each blue-fish is not excessive, which gives ten thousand million of fish destroyed by them daily, and as the stay of the blue-fish is about one hundred and twenty days, we have, in round numbers, twelve hundred million millions of fish deroured by them in a season. "Again, if each blue-fish areraging five pounds, destroys even lialf its own weight per day, we will have during the same period, a daily loss of twenty-five hundred million pounds, equal to three liundred thousand millions for the season." These are stupendous figures, absolutely bewildering, and would not be quoted but for the fact that they have been prepared by so reliable an authority as Professor Baird. When the blue-fish season arrives, you will hardly be at a loss where to look for them. Sometimes Barnegat Bay is literally alive with them, as is Great Egg Harbor Bay. Outside is the place to look for them, and the various inlets are the cliannels of egress to where they abound. 


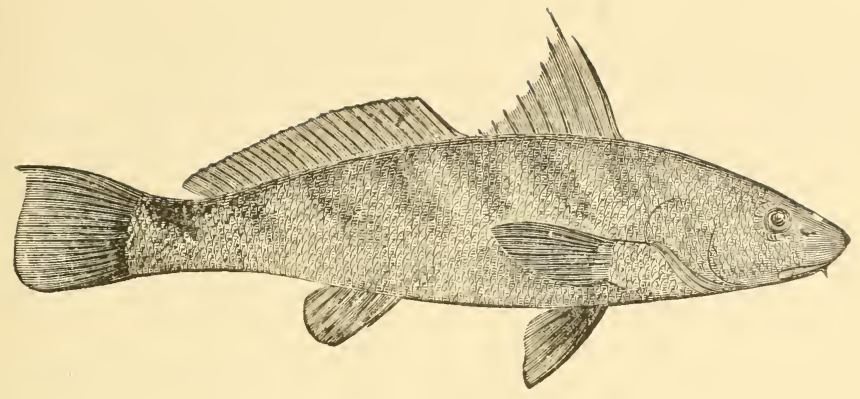

THE KING FISH.

HAKE-WHITING-BARB.

(Menticimus nebulosis.)

This fine representative of sea food-fishes has always enjoyed a most enviable reputation, whether for the table or for gameness when hooked. In such high esteem was it held by the New Yorkers in colonial days, that in order to show their high appreciation of its many admirable qualities, they called it the King fish, considering the appellation mutually complimentary to the fish and to the King.

It needs not the telling to those familiar with the edible characteristics of the King fish, that they rank with the best, and are generally held in such repute by fish epicures. For its size, it is one of the heaviest of fishes, which is largely due to the fact that it is remarkable for the solidity of its flesh, and for the comparatively small portion of the fish itself which goes to waste in the cleaning. The flesh is pure white, of close, laminated, flaky texture, and whether for the pan or for chowder, is preferred to most others by those who claim to be experts in fish preparation and eating.

Although not in any way related to the weak-fish, the King fish appears to be very foud of his company, as is evidenced by the fact that the two are so frequently taken on the same 
grounds. So common is this companionship, that as recommended in describing weak-fish tackle, it is always advisable to have a small hook for the bottom one, and it on the ground, in order to accommodate the King fish.

It is most conmonly found on a clean sandy bottom, preferring the edge of channels and sand bars during the flood-tide, retiring to the deeper waters as the tide recedes. It makes its appearance co-temporaneonsly with, and departs abont the same time as the weak-fish. At times it is exceedingly plentiful. The season of I888, as was that of 1880 , was noted for the abundance and size of the King fish along the entire coast, but especially at Anglesea, where the writer and a friend took an hundred and sixty-eight on a single tide, most of them of good size and some of them very large for those waters.

It is gregarions in its habits, running in schools, and frequently remaining in one locality as long as toothsome bait is furnished by the fishermen.

As to the ganneness of the King fish, there can be 110 dispute. Its claims to distinction in that respect, are very strong eren among the smaller ones, but when a two or three pounder is looked, all doubts on the subject are remored. It is a free, in fact a rarenous biter: not so impulsive as the weak-fish, but fully as earnest, taking hold with a vin that leares 110 room for the inference that business is not meant. Seizing the bait in a lively manner and without nibbling or hesitation, he only needs the prick of the hook to start him off at a rate of speed that fairly astonishes. Swimming low, his runs are generally long ones until he is brought up on a round turn by the angler, when he changes his tactics, and if the water is deep, resorts to the methods adopted by the sheepshead-diring downward repeatedly, and if he is a two or three pounder and you are not on the alert - the tip of your rod is almost certain to be drawn under the water. The persistence with which he maintains his struggles to escape, fairly entitles him to the designation given to him by Scott, "the king of game fishes." 
As already stated, the King-fish is of the botton kind, and must be fished fo: there. Having a small month, a small strong hook is requisite, and a correspondingly small bait. In angling for it, do not make the mistake of offering a large bait. A two foot leader looped about a foot above the sinker, is a good rig, but it will, the writer thinks, be found a more certain method to have a single gut snood looped three or four inches above the sinker. With a light springy rod, and correspondingly light tackle, in water of from ten to fifteen feet in depth, and with King-fish plentiful, no better angling sport could be desired.

- As already remarked, plentifulness of the King-fish is not always an assured thing. Sometimes they disappear almost entirely from the estuaries, remaining absent for two or three years, then suddenly reappear in great numbers and of large size.

Although not renarkable for beauty of coloring, it is far from being a homely fish in that respect. It has many handsome tints, and when first taken from the water is a comely creature, making up in gracefuluess of form and adnirable proportions for strength and endurance what it lacks in other particulars.

The King-fish is not fastidious in its tastes. Hard clam bait, cut small, is always acceptable; shedder crab is never refused, black-mussels are greatly relished, and fish bait cut from the side of a small sea bass is always welcomed.

\section{THE SPANISH MACKEREL.}

\section{(.Scombcromorus maculatus.)}

The Spanish mackerel, whether for beauty, swiftness, grace, gameness or edible qualities, fairly challenges comparison with any other fish that swims in salt water. Although taken at times along the entire Jersey coast, it is rarely numerous there, and when it does appear in any considerable abundance, is generally found far from the shore-farther than where the blue-fish usually forages. Being evidently finer constituted than that bold bucaneer, less 
strongly built and not nearly so belligerent, the Spanish mackerel, although a snappy and vigorous biter, lacks the well-known powers of endurance and the persistent pluckiness of the blue-fish. He fights while he cloes fight with all his might, but his struggles are not protracted, and when he gives 11p, he does so entirely. His surrender is complete, and when landed, he displays faint evidence of the fiery vigor that only a few monents before, characterized him.

\section{HABITATS AND HABITS.}

For a long time, indeed until r880, the most earnest and extended investigation had failed to discover the spawning grounds of this fish, when it was annonnced on what is now nndisputed authority, that the lower end of Chesapeake Bay was one of the principal localities.

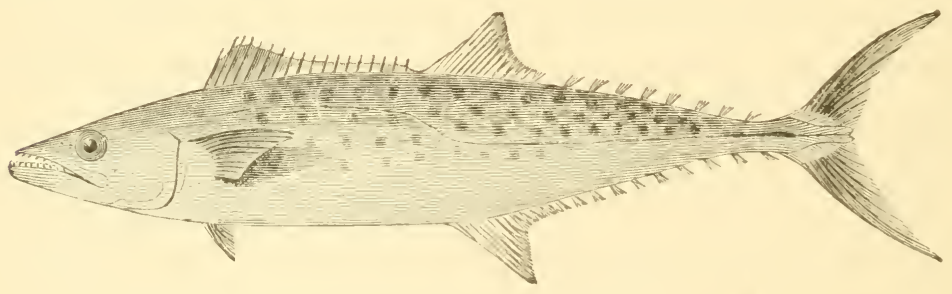

SPANISH MICKEREL.

Sereral years ago, the writer was astonished while visiting Crisfield, at the lower extreme of the eastern shore of Maryland, to learn that Spanish Mackerel were taken in that ricinity in immense numbers; several thousand having been canght at a single seine-hanl, a short time previons. The abundance there and the whole way down to Cape Charles still continues, though the fish are small and exceedingly shy, rarely taking the bait, but when they do, showing vigorous fight.

Although the companion of the blue-fish in its murderous maraudings, the Spanish mackerel is not a frequent prize for the 
troller, which may be in some measure accounted for by the facts that the squids used for blue fishing are too large for its comparatively small mouth, but more reasonably, because it is less inclined to feed in that way than its more greedy companions. Possibly some of these days a lure will be derised that will tempt and capture it more readily.

\section{ECoNomic Value.}

At present, nearly all that are sent to market are taken in seines and pounds, but the number has never been sufficiently large to bring the price down to figures that enable any other than the affluent to have it grace their tables. It has been computed that at twice the price ordinarily paid for the best sea fishes, the Spanish mackerel is the cheapest, leaving excellence in other respects out of the question. Having an exceedingly small head and a stomach of the most limited capacity, nearly the entire fish is eatable, and those who have partaken of a fresh one nicely broiled, need not be told that in point of flaror and delicacy it may have a peer, but certainly not a superior.

The Spanish mackerel makes its first appearance in June, about the time of the arrival of the blue-fish, but its stay is shorter, as it cannot abide colder water than $60^{\circ}$, and will not remain any time where the temperature is as low as that. It leares before the blue-fish, and like the shad and other migratory fishes, goes to unknown waters. By the middle of September they are usually non est inventus.

The finest that reach our market come from Seabright and other localities on the North Jersey coast. They are taken there of good size, much larger than at the mouth of the Chesapeake.

\section{THE SHEEPSHEAD.}

A glance at the fine illustration will give the reader a fair idea of this peculiar fish, peculiar in shape, as well as in some of its 


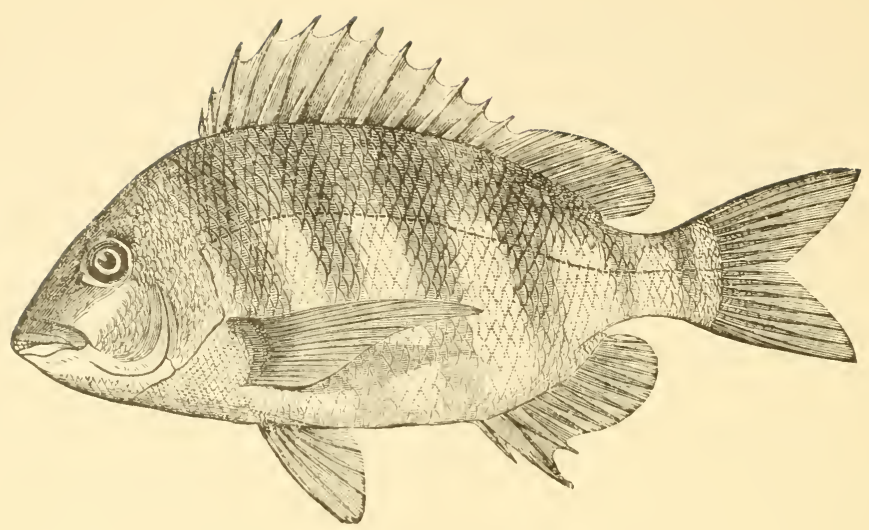

The ShenpsheaI).

(Sargus oris.)

other leading physical characteristics. Its name is derived from the marked resemblance of the front teeth to those of the sheep, and a very appropriate name it is. In addition to the front teeth, which are used for wresting from their fastenings, barnacles and other crustaceans, the mouth of the Sheepshead is pared or covered on the upper and lower jaw, with a sort of tootli-mosaic, with which powerful, apparatus, mollusks and barnacles are readily crushed and their neaty contents appropriated.

\section{HANDSOME Fish.}

The sheepshead, as it usually seen on the fish stalls, is dull and dingy looking and far from inviting in appearance; but such is not the case when first taken from the water. Its scales are large and brilliant, the crescent-shaped bands are a deep rich black at the back, gradually lightening to a gray tint near the belly, and its magnificent equipment of fins is displayed to the best advantage. Taken altogether, it is when alive, one of the most beautiful of sea fishes, as it is one of the most gamey and toothsome. 
To capture a Sheepshead is one of the longings of most fishermen, many of them spending days in a vain effort to achieve such a triumph. But Sheepshead fishing is one of the fine art branches of angling, though, until within a few years it was mostly done with the hand-line. But now, as in the case of nearly every other kind of heavy sea-fishing, the rod-and-reel are most generally used, much to the enhancenent of the anglers' enjoyment.

\section{Time of ArRival.}

Like all tropical fishes that find their way northward, the time of the Sheepshead's arrival is generally presumed to be regulated by the temperature of the water, being rarely caught along the coast of New Jersey before the first of June, where, some seasons, they come in great numbers, and in others in only small detached parties. The writer has seen thousands of them off Brigantine Beach lying or resting upon the bottom, all attempts to induce them to bite proving mavailing, though half an hour thereafter, several fine ones were taken at the "wreck" not more than a fourth of a mile away.

\section{How They Bite.}

In southern waters, especially on the Gulf coast of Florida, they are readily tempted with fiddler crab, and on the Atlantic coast of that State, 110 more attractive bait than a small bit of the hard part of a clam is needed. They bite quickly and must be snubbed at the first indication of a bite, if fiddlers are used. Along the Jersey coast, where the fish are larger and in finer condition, they are more wary about bait-taking, biting with a great deal of deliberation, as though the biter was not hungry. But slow and cautious movements must not be accepted as meaning anything less than the securing of the bait. He goes abont it his own way, taking more time to it than is usually consistent with angling temperament. The least disturbance of the bait is apt to stop the nibbling 
or sucking, as the Sheepshead is not in.the habit of feeding upon moving provender. Patience and quiet are the virtues needed, and their full exercise is peremptorily demanded, if success is desired. You may be rewarded with a bite at once or you may spend a whole day in the vain endeavour, therefore, prepare yourself in advance, for a wait.

\section{CAPTURING A SHEEPSHEAD.}

If the fellow you are after is of the more impetuous kind, all the better. Your enjoyment will be so much the greater. Many a listless angler has caught a Sheepshead, by simply failing to have discovered that one was mouthing his bait. IVhen full hold of the bait is taken, there will he no longer occasion for hesitation. Strike and prepare for a contest. If inmediately upon being hooked, he shoots towards the surface-as he is very apt to do-take in all the line you can in the little time allowed you, for he is certain to make a dive towards the botton1, and the novement is so speedy as to require you to have rod-and-reel in position for the rusli. Let him have line, but restrain his movennents by keeping it tant. If he repeats his sudden downward swift plunges, continue to humor him as advised, until, ultinately, you will find his dashes less frequent and violent, and you will begin to think you have about won the day. But be not orer-confident. Irhen he nears the surface, drawn thither by the line, he becomes desperate and makes his final and not unfrequently successful effort to get away. Be prepared for it. Have your landing net ready and take him in if you can. If he goes down again and fails to break your hook or your leader, you may then pretty certainly calculate upon victory. Where the hand-line is used and main strength is pitted against fish power, the contest is not so prolonged, nor is the pleasure nearly as great.

HOOKS, TIDES, ETC.

The breaking of the hook is not so much due to the strength or struggles of the fish, as to the fact that it is apt to be caught at 
disadvantage, between the powerful crushing teeth. If the fish is hooked in the lip, escape is not nearly so probable, but, as you can't fasten the hook just where you want it, you must take your chances with the "sheep." The best time of tide for taking Sheepshead is what may be termed medium tides, that is, an hour before and after high and low water, when the current is comparatively slack, for the Sheepshead is not fond of swift water.

\section{BAIT.}

As to bait, a number of kinds are used. A favorite one along the Jersey coast is the razor clam, but it is not always procurable. Sand clams are also acceptable and good sized lively fiddlers generally welcome. The Sheepshead has a soft side for a piece of shedder crab, but whaterer kind is selected-save fiddler-a bait-string should be used in order to prevent smaller fish from readily nibbling away the tempting morsel.

\section{TACKLE.}

As to tackle, only that of the best quality should be used. A twelve thread cable-laid Cuttyhunk is strong enough, and though nearly every tackle dealer has hooks made specially for Sheepshead, and charges a good round price for them because they are hand-made, strong and sharp, the writer has found the largest sized Chestertown adequate for the purpose. It is a mistake to use very large hooks as so many do, though the practice is falling into disuse. But a strong hook is requisite, whatever the size.

A light sea-rod or a stout bass rod will answer, and it should not exceed eight feet in length. and should be furnished with the kind of reel recommended for general sea-fishing.

\section{HABITATS.}

Sheepshead, although sometimes taken in what, experienced fishermen term, out of the way places-have haunts, where they 
usually keep, and where they must be sought; in the vicinity of wrecks, as the famous iron one off Brigantine Beach, or those a mile from Hereford Inlet, seaward; along steep, soddy, meadow banks, where the water is deep and the tide does not ru11 too strong. In Barnegat Bay, at several points, they are at times very plentiful and are canght in large numbers-near Tuckerton, Beach Haven, Barnegat Inlet, in the deep water off Forked River, and at the bridge that crosses the Bay near Toms River. The thoroughfares above Atlantic City and Long Port a few miles below, are excellent points, as are Great Egg Harbor and Corson's Inlets. The two latter places can be reached by rail to Sea Isle City, thence to Ocean City, where all kinds of sea-fishing may be had in season. At many places in the sounds between Cape May and Townsend's Inlet, fishermen have fine sport, and those who desire to partake of it, can hardly go astray by visiting any of the localities named.

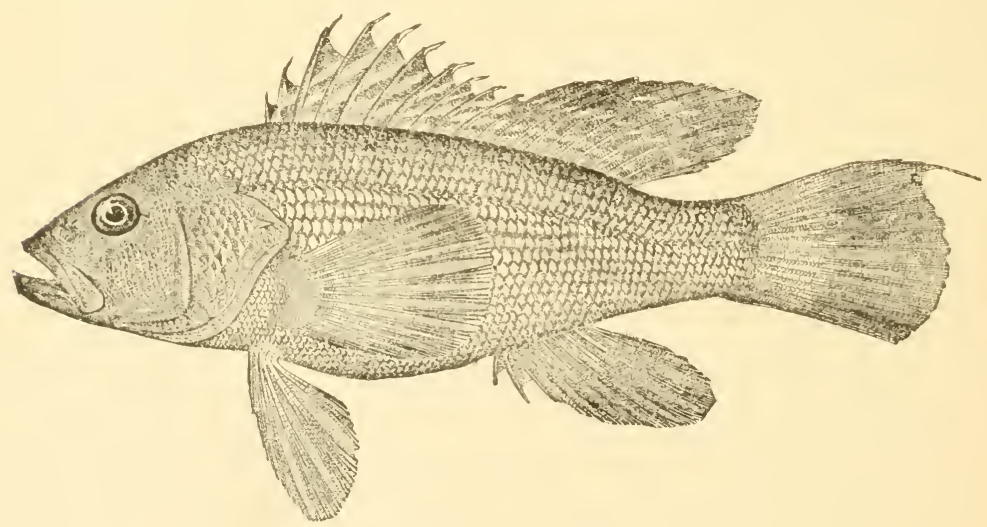

THE SEA BASS.

(Centropristus atrarius.-Iinn.)

Here we have a fish known to nearly all who have ever cast a baited hook in salt water along the Jersey coast. It is, perhaps, more abundant-size not considered-than any other. It is not a game fish, but what it lacks in that respect is fully made up in its 
estimable qualities for the table. For chowder, boiling or frying, it has few superiors, the flesh being pure white, laminating in compact flakes, just juicy enough to be agreeab!e, and of a flaror that is hardly surpassed by any other sea fish, when properly served.

The Sea Bass is usually a bottom fish, and must be sought there or not at all. Like nearly every other sea fish, this one has a score or more of names. Its habitats are almost everywhere along the coast, in the bays and sounds when young, and adults in inınense numbers outside at many places. The Sea Bass is found in almost any of the coast waters where rocks or ledges abound; along the soddy banks of the thoroughfares, but especially on what are known as the "Banks," a number of which exist along the coast from Cape May to Long Branch. The Five Fathom Banks off Cape May, those about six miles from the shore, opposite Anglesea, and several others farther north are noted for the number and size of the Bass taken on them. The water ranges from thirty to sixty feet in depth, and those who care more for quantity than for genuine sport, can indulge their inclinations to the full there. Large sloops and schooners visit nearly all of the "banks" daily, generally taking out full complements of passengers, who pay a dollar for the passage, are provided with line and bait, and are entitled to all the fish they catch, the number being larger, generally, than they can carry with them. Those "bank" Basses range in weight from half a pound to five pounds or more. They are ravenous feeders, taking clam or fish bait with equal avidity, and giving full employment to the fishermen as long as they feel disposed to bait, cast and pull up their spoils.

The rod for such fishing should be a stiff one, as a heavy sinker is required, and if two or three hooks are used, the chances of taking big fish on each one are good. As the tendency of the Sea Bass, when hooked, is down and downward, the reeling of them in is simply hard work. Hooks of medium size are best, and as the mouth of the Sea Bass is large and of the leathery order, when once hooked capture is almost certain. They bite most freely during slack water. 


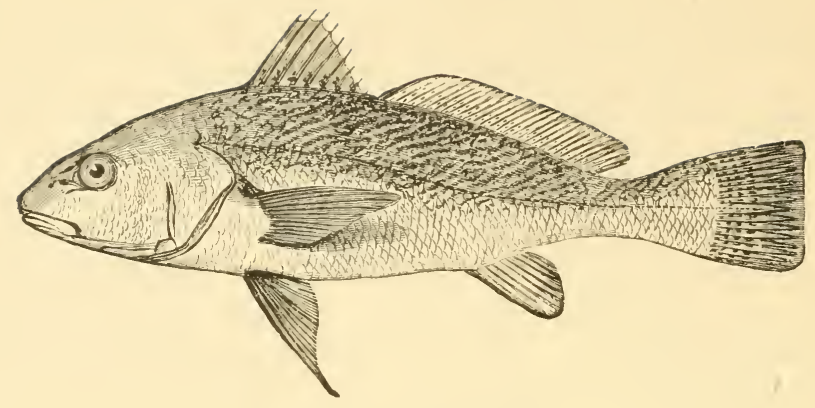

THE CROAKER.

(Micropagus undulatus.-Cuvier.)

Eight years ago, the Croaker was nnknown to the hereabonts present generation. About that time it made its appearance in immense numbers along the entire coast of New Jersey, causing a great deal of excitement among sea-fishermen. Whence they came, where they belonged and whether they had come to stay were leading questions. A few reterans whose memories carried them back some forty or fifty years, remembered a like visit, and that was all. The second year they returned in diminished numbers, their abundance decreasing until now only an occasional one is taken. It is an outside, bottom fish, consorts with the weak-fish, takes the same bait, is a ravenous biter, with leathery jaws and a moderate sized mouth.

In southern waters they are always abundant, and are fairly esteemed for the table. Those taken here were not regarded with much favor, except for the fun of catching them. They ranged in weight from half a pound to two and a half pounds. The writer weighed a dozen taken by him, which drew the scales at thirty pounds.

\section{THE SPOT OR GOODY.}

This lively little fish is noted alike for its vivacious habits and its excellence for the pan. Although the angler in salt water is 
very apt to make its acquaintance in the course of a day's fishing, it is not always abundant north of the mouth of the Chesapeake. Sometimes spots appear in immense numbers. The writer saw so many caught at a single haul of the seine at the Breakwater a few years ago, that difficulty was experienced in Lewes in getting wagons to take then away.

The Spot, so called from the dark mark near the gill-corer, is also known as the "Lafayette," from the fact of its having appeared along the coast in great numbers in I824, the year of

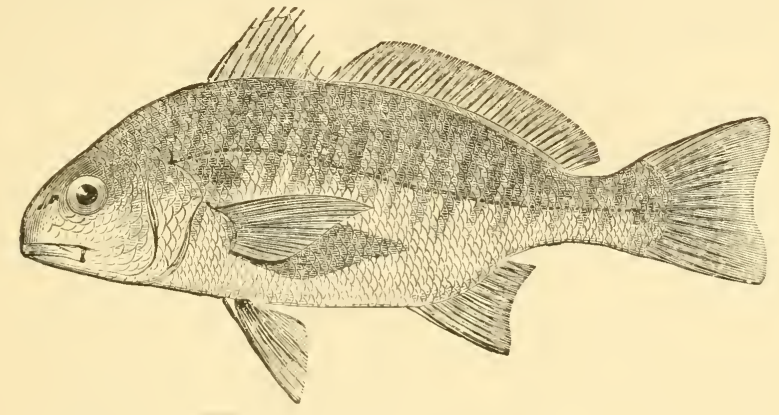

The Spot or Goodr.

(Leiostomus xanthums.)

General Lafayette's visit to America. They have no special habitats, being found in greater or less abundance all along the coast. They are rexatious little scamps, as they give a sharp nibble and then dart swiftly away. If you find them plentiful, rig your lightest line and rod with three or four very small and very sharp hooks, and let your bait be ditto. Clam is readily taken, as are small bits of fish, with the skin adhering.

Professor Baird said of it, " Of the smaller pan fish of our coast, in excellence of flavor, none is considered superior to that known as the Lafayette," an opinion that will be fully endorsed by all who have tasted that fish, nicely fried and served hot. The approved method of frying them is to swim them in boiling sweet oil, or pure sweet lard. 


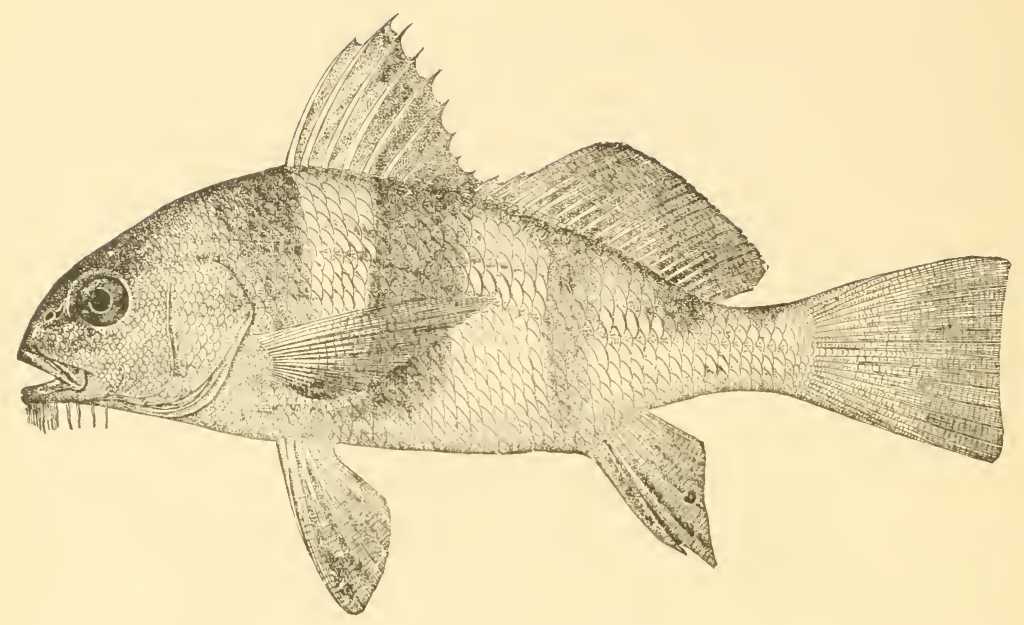

THIE BIAC'K IORTM, (Young.)

\section{(Pogonias Chromis.)}

The name of this fish is derived from the fact, that it makes a noise not unlike that of a drum, or the twang of the heavier string of a bass fiddle or of a piano. The drumming is frequently heard by fishermen while sitting in their boats awaiting a bite, as well as when the fish is landed. IThen heard in the water, it is generally an indication of the breeding season, the londer notes supposed to be the call of the male fish to his mate, the fainter ones the response, though that is simply conjecture.

\section{HABITA'TS AND HABITS.}

The Black Drum-so called, is perliaps the largest fish with which hook and line fishermen are called to contend along the seacoast and on the sliell beds on the Jersey side of Delaware Bay, for a considerable distance above Cape May. It is a very solid fish, sluggish in its habits. with a great depth of body compared with 
its length. It is not handsone, the prevailing color being a bronze, partaking largely of the brown. The body is covered with an exceedingly heavy coat of scales, which in the larger fish are very difficult to remove, a garden hoe being sometimes used for the purpose. The teeth are not of the cutting order, but blunt and strong, and evidently intended for grinding and crunching mol1usks of almost any kind. The Drum is charged with being very destructive to the oyster beds, though there is no absolute evidence on that point. It is fairly presumable that with such a formidable crushing apparatus and with the Drum's well-known fondness for shell-fish of nearly every kind, if hungry, as it generally is, it would not pass an oyster bed without testing its qualities.

\section{Surf Fishing FOR DRUM.}

The usual method of fishing for Drum along the coast, in the surf, is with the hand-line, with a heary sinker attached; the hooks being fastened above the lead. The fisherman having baited his hook with a good sized, whole clam, secured with a bait string, takes his position either on the beach or in the water, and makes as long a cast as possible. Notwithstanding the weight of the sinker, the constant action of the wares urges it towards the shore, the fisherman taking in the slack line, which he coils in a box or small bucket suspended from his neck. The Drum is frequently taken where the water is so shallow as scarcely to hide his body.

\section{ROD-AND-REEL, FOR DRUMI.}

Another method is with the rod-and-reel, which has almost entirely superseded the hand-line, except with the old-timers. Strong tackle is of course required, as the Black Drum ranges in weight from ten to seventy or eighty pounds. In Delaware Bay, where the "shell beds" are a mile or more from the shore, Drum fishing is done from boats, which is much more pleasant than cast- 
ing for them along the beach. The baiting is the same, the only difference between the two methods being, that when a good sized drum is hooked in the surf with a hand-line, the contest is one of physical strength, while in the rod-and-reel hooking, it is one of skill. They scarcely ever bite except while the ticle is running up.

The illustration represents a young fish, which differs from the adult in color as well as in shape, the color being lighter and the body banded or striped as shown. It is besides, more symmetrically formed and decidedly handsomer than the adult.

The season for Black I)rum fishing begins early in May along the sea coast; a little later in Delaware Bay. It is a fish of little economic value when of large size, the flesh being dry and insipid. The younger fish are more toothsome, but they are rarely seen in "near-by" waters.

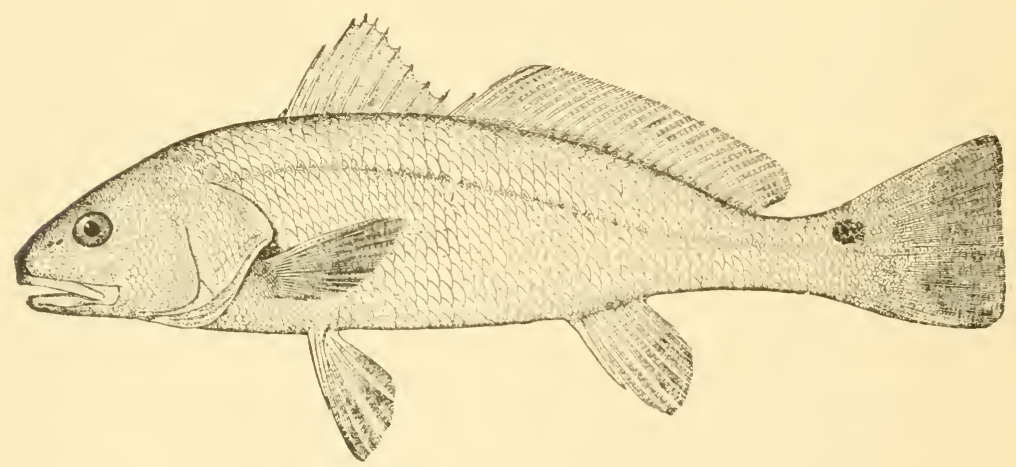

THE RED DRUM-CHANNEL, BASS.

(Scana ocellata.)

This is essentially the game fish of southern salt waters, taking in respect to that quality, the precedence of all others. It is not a frequent visitor to the Jersey coast, but is sometimes found there, and when found and hooked, the person hooking it likely to make 
note of the fact. Although of the Drum family, giving utterance to the same drumming noise, as the Black Drum, it differs from that variety in shape, and somewhat in habits, It is lighter in color, is thick-bodied but more slender, and has one or more black spots, the number on the tail ranging from one to eight or ten, and without regular arrangement. Sometimes there is an entire absence of the spots. Just why it is called the Red Drum, can hardly be rightly attributed to its color. Goode says: "The chief objection is, that the fish is not always red; in the young, there is not a suggestion of this color, while in the adult it is more a tint, an evanescent metallic reflection of claret from the scales, which is often absent, at all erents, soon disappearing after life is gone."

The biting of the Red Drum does not generally correspond with its other vigorous habits, as it is prone to nibble at first as if testing the quality of the bait, then coquettes with it, sometimes carrying it a yard or more, when the inexperienced angler is apt to pull, but it is not safe to do so until he darts away with it at great speed. However, Red Drum are so scarce on the coast that no instruction need be given for their special capture, and none can be as to their particular habitats, except that they are more frequently taken in the surf than elsewhere, and occasionally on the shell beds in Delaware Bay.

\section{THE SCUPPAUG-PORGY.}

\section{(Stenotomus chrysops.)}

This is an important fish commercially considered, known in many places along the coast as the "Scup," remaining pretty much all the year round, though most abundant in June and July. Professor Baird says the bigger fish make their appearance first, the smaller ones following in graded sizes, the smallest coming last. The largest average from two to four pounds, and are said to be the breeders. They do not bite readily early in the season, but when done spawning, feed vigorously. 
The Scup or Porgy feeds upon worms, small crustaceans, mollusks, etc., taking the bait freely, the smaller ones beconing very

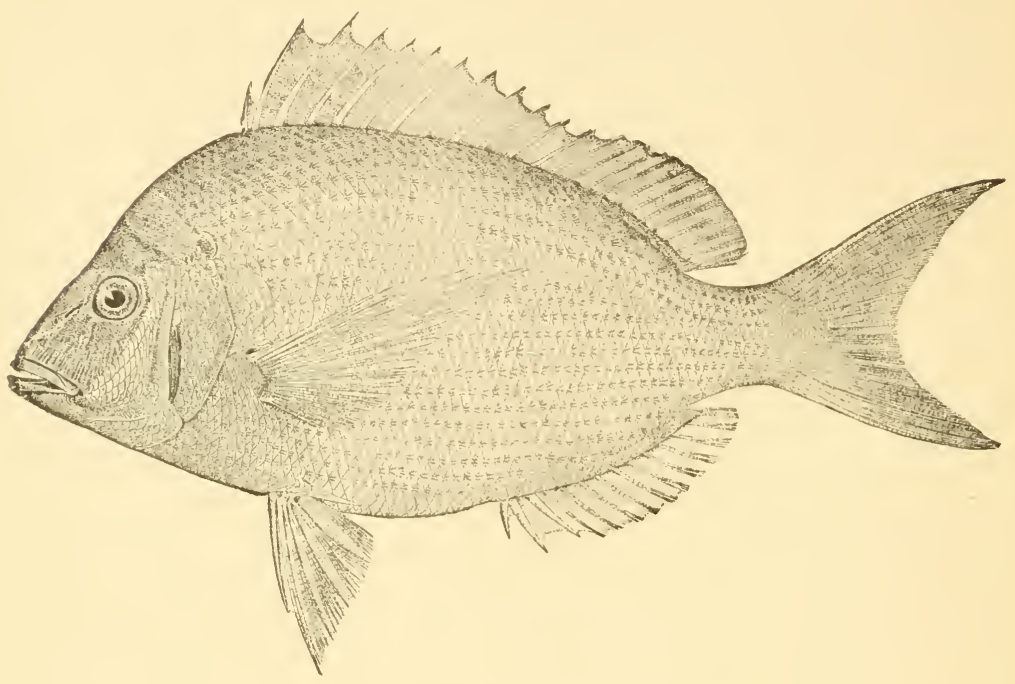

THE SCUPPAUG-PORGY.

annoying at times, because of their excessive greediness. It is a bottom feeder, rarely found in shallow water, and always avoids, if possible, that which is discolored.

\section{HOW TO FisII FOR PORGY.}

The Porgy is an adroit bait-robber, its sharp perch-like teeth, enabling it to purloin that which was intended to be partaken of only in connection with the hook. It is most abundant on the coast of New England, and in the vicinity of New York, steamers carry large numbers of fishermen to the Porgy banks. They are at times equally abundant at points along the Jersey coast, but have no particular place for rendezvousing, therefore, it would be 
impossible to designate precisely where they are to be found. If, in the course of a day's fishing, they are net with in considerable numbers and you desire to take them, rig your tackle as if for perch, cover the point of the small hook well with clann or crab-bait, have a pair of snells, swivel sinker, and fish near or on the bottom.

The flesh of the Porgy is much relished by some, but others pronounce it dry and tasteless, its juices being rapidly absorbed in the cooking; still it is by no neans a fish to be despised.

\section{STRIPED BASS SURF FISHING.}

Under the head of Striped Bass, it was promised that farther on. something would be said in regard to the taking of that fine fish in salt water. Although the female never deposits her eggs in the sea-but in fresh and brackish waters-the finest sport is found with this fish along the sea-coast and in the estuaries. It is only within a few years that Striped Bass surf-fishing has become popular along the Jersey coast. For years, casting for Striped Bass from the rocky shores of the coast North of New York has been popular, and it needs not the saying, exciting in the highest degree. As that is not within the "near-by" 'bailiwick, we pass it by, to give place to the surf-fishing along the coast south of Long Branch.

\section{Some Notable Near-bi Places.}

The rivalry has been very strong there, each fisherman being anxious to outdo his opponents in efforts to capture the biggest. Some of the contestants have had marked success, especially in the ricinity of Key East and Asbury Park. At the former place, a Striped Bass weighing forty-two pounds was taken with the rodand-reel, and 1nany others of smaller, but still very large size. Elsewhere along the coast, handsome surf-catches have been reported, and every year the sport becomes more and more popular, and the rivalry stronger. 
That it is in the highest degree exciting, is evidenced by the zeal and determination displayed by the fishermen, who spare neither expense nor time in preparing for the contest. Some fish all day without a nibble, others land splendid fellows.

\section{TACKLE FOR STRIPED-BASS SEA FiSHING.}

The tackle nunst necessarily be strong and of the best. As long casts have to be made, a sinker from two to four onnces, and a stout stiff rod are essentials. The rod should not be so stiff as to render it unwieldy and awkward to handle. Shedder crab is the most taking bait, and as the casts are long and always swift, the bait should be secured with a stout thread. An eighteen thread Cuttyhunk line and a number 6 or 7 Sproat, a number 5 or 6 O'Shanghnessy or a Limerick of the same number of hook are annong the requisites. As the fishermen ustrally stand in the water while fishing, hip gun1-boots should constitute part of the outfit, together with a gaff.

\section{IN THE ESTUARIES.}

Less pretentious but equally satisfactory Striped Bass fishing is found in nearly all the estuaries-notably in the sliallow creeks or thoronglifares in parts of Barnegat Bay, Great Egg Harbor Bay and in the vicinity of Townsend's and Hereford Inlets. The best time, when the tide suits, is early norning or near sundown in the erening. The fish do not run as large as those taken in the surf, but they are apt to be more plentiful and of sufficient size to insure fine sport. Being of wary habits, quiet is essential to success. The best season for salt water Striped Bass fishing is from the latter part of August until the last of October, though they bite fitfully during the entire summer. 


\section{For Good Fishing,}

Boating, Crabbing and other Summer Pleasures,

GO TO

1๑

On the New Jersey Coast, midway hetween New York and Philadelphia, six miles south of Long Branch. First-class hotels, good drives. Excellent opportunities for profitable investments.

For particulars, address,

\section{Edward Batchelor,}

Jume,

July,

August,

september,
1231 Chestnut Street,

PHILADELPHIA.

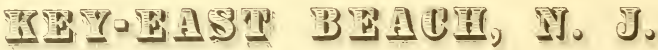

If you Smoke,

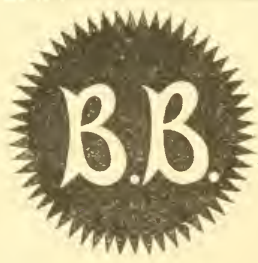

'TIS

Batchelor

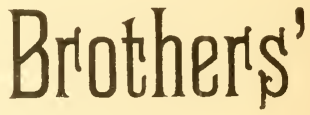

Flor DeBatchelor,

HIGH GRADE and BUMBLE BEE,

"BUTTON"

NICKEL

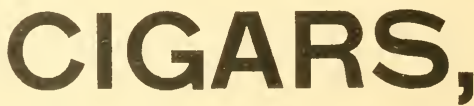

FACTORY No. 1, 1231 Chestnut Street, Philadelphia.

For Sale EVERYWHERE. 


\section{Porler}

Publishers,

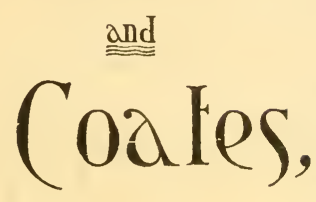

Booksellers

מND

\section{ImporFers,}

Dinth and Chestrul Streels.

米米溇

AMERTCAN FISH CULTCRE.-By Thuddens Norris. Embracing all the details of Artificial Breeding and Rearing of Trout; the Culture of Salmon, Shad, and other fishes.

Illustrated $12 \mathrm{mo}$. Cloth, extra, _ $\quad$ - $\quad$ - $\$ 1.75$

-AMERICAN ANGLER"'S BOOK.-By THaddens Norris. Embracing the Natural History of Sporting Fish, and the art of taking them; with instructions in Fly Fishing, Fly Making and Rod Making; and Directions for Fish Breeding. To which is added Dies Piscatoriæ; describing noted fishing places, and the pleasures of solitary fly fishing. New edition, with a supplement containing a description of Salmon rivers, inland Trout fishing, etc. With 80 engravings. 8vo.

Cloth, extra, bev. boards, gilt top, - ${ }^{*} \$ 5.50$

STONEHENGE.-Encyclopadia of Rural Sports. By J. I. Wralsh, F. R. C.S. (Stonehenge). Comprising Shooting, Hunting, Coursing, Fishing, Boating, Racing, Pedestrianism, Cricket, Base Ball and the various Rural Games and Amusements. With 200 engravings.

Crown 8vo. Cloth, extra, - $\quad$ - $\quad$ - $\$ 4.50$ 
REED \& GILDNER, $=====$ GUIN MARERS.

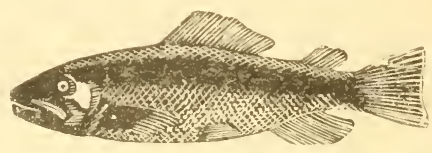

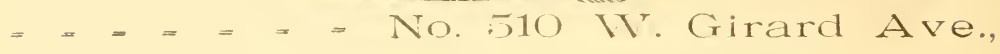
Manufacturers of and Dealers in PHILADELPHIA.

\section{Guns, Pistols, Fine Bamboo Fishinó Rods,}

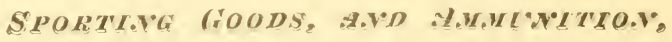

Fishing Tackle of Every Variety, also Trout Rods on hand and made to order. Parties fitted out for all kinds of Se:a Fishing. Shells loaled with the greatest of care, for all kinds of Breech Loading Guns.

All kinds of Jobbing promptly attended to.

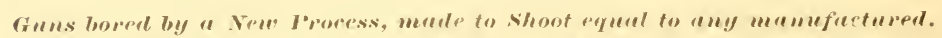

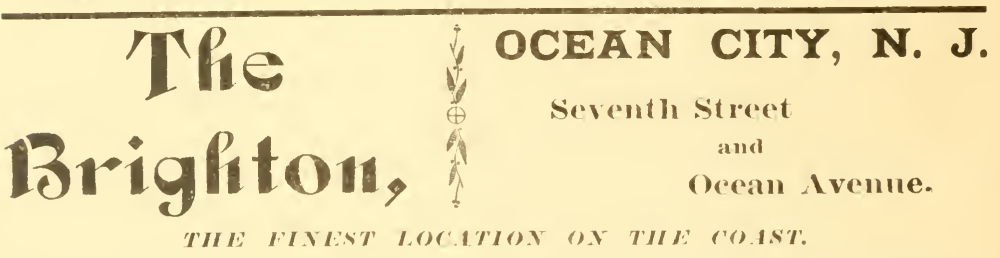

Rates, $\$ 2.00$ per day.

R. R. SugY, Prap'r.

For plan of Hotel, call at Soor's Labifs' Axd Gext s Diving Rooms,

52: C'hestnut Street, Philadelphia.

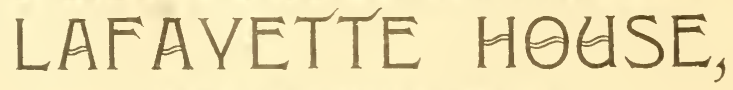

Forked River, N. J.

B. E. ENO, Proprietor.

(formerly Joseph РАвкеR.)

A Finest Fishing Grounds on Barnegat Bay.

Coaches meet all trains FreE.

Coarches to and from Boats Free. 


\section{Philadelphia Fishing T'Tackle Mtouse,}

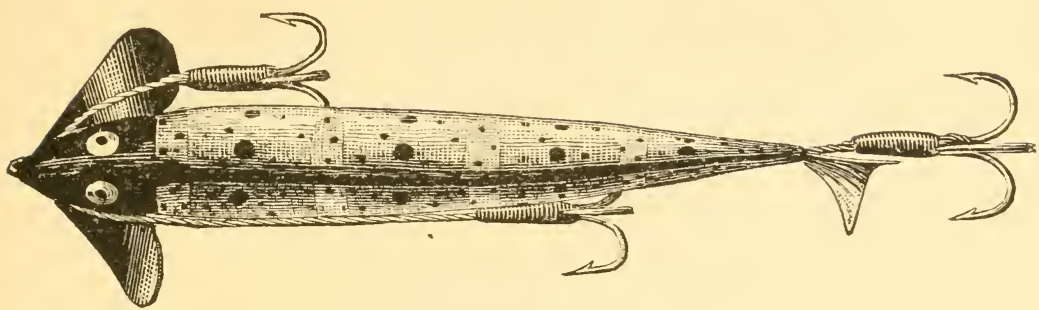

MANUFACTURERS OF

FISHING TACKLE OF EVERY DESCRIPTION, A specirlty of the Celebrated Buthubrure Wool Fly, Buit and Sert Rods. Shipley's Patent MOTH PROOF FLY BOOKS, \&c., \&c.

Every description of Rods and Reels repaired.

Send 10 cts. in Stamps for New 90 page Illustrated Price List.

\section{A. B. SHIPLEY \& SON,}

\section{0:3 Commerce Street,}

PHILADELPHIA.

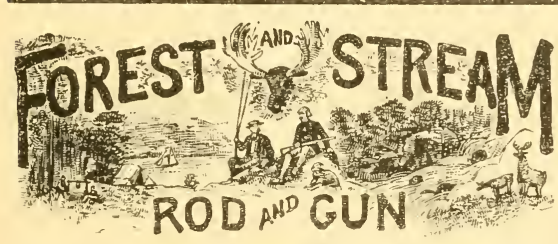

The Angler who wants to get fish, whether from fresh or salt water, must read the Forest ani Strean. Sample copy sent for io cents. Our books on angling are also indispensable to the fisherman. A handsome illustrated catalogue sent free to any address. FOREST AND STREAM PLB. CO., 3IS BROADWAY, N. Y,

\section{Fuuntain Head Spring} OF SOUTH POLAND, MAINE,

Is the Primary Source of the Celebrated

\section{SOUIII POIAIVD WAIEF.}

If you desire the best and purest of the medicinal drinking waters for KIDNEF, STOM ACH and other ailments, drink no other Water, as it has no equal.

Ask for POLAND SILICA WATER, PRINCIPAL DEPOT, 503 Chemy St., Philad'. For Sale by the Barrel or Gallon,

Telephone 1639 .

J. B. WICKERSHAM. 


\section{Are You Fond of Angling?}

\section{THE AMERICAN ANGLER.}

Twenty-eight pages; is issued weelily, and each issue contains valuable illustrated contributions and editorials on Fish, Fishing and Fish Culture; Notes and Qneries as to the Habits, Habitat and Modes of capture of Game and other Fish; Reports of Fishing (in season) from all parts of Anerica, etc., etc. It is the Fisherman's l'aper-the only one in America. $\$ 3,(w)$ a year.

\section{THE ANGLERS' GUIDE TO THE FISHING WATERS OF THE} UNITED STATES AND CANADA.

By William C. Harris, Eulitor "American Angler." This book is invaluable to the angler and tourist. It tells how eight thomsanil fishing waters are reached, the species of fish therein, hotel areommodations and cost, charges of gnides, hoats, etc, baits used and best months for fishing. Handromely boumd in eloth. Price \$1.00.

\section{THE TARPON OR "SILVER KING."}

By F.S. Pickney ("Ben Bent"). History and methods of capture. This royal fish, the largest taken with rod and line, is fully described, also the ontfit needed for his capture, Handsomely bound in clotl, gold and silver. Price, post-paid, $\$ 1.50$.

THE NEW AGRICULTURE; OR, THE WATERS LED CAPTIVE.

This work describes the methous disovered by IIon. A. N. Cole, throngh which the farmer and the narket garlener ean incrase their crops fourfold. The system prorides effectually against the efferts of dronth and frost, and is indorsed by all the prominent tarmers' elubs and other agrieultural authorities. Fully illustrated and handsomely houm in eloth and gold. Price $\$ 2.00)$, postage free.

PORTRAITS OF GAME FISHES.

On gray tinted Bristol board, $7 \times 9$ inches, at the following prices, post-patal : Single copies, 10 cents; Fresh Water series (2:3) at $\$ 2.00$; Salt Water series $(37)$ at $\$ 3.50$, whole series (60) at $\$ 5.00$.

\section{THE SPORTSMAN'S GUIDE TO THE HUNTING GROUNDS} OF THE UNITED STATES AND CANADA.

By Willian (: II:mris, Eelitor "Aureriean Angler." Many thousand of shooting and hunting grombls accessible to the tield sportsum are herein locatmi, the greater number being tabulated from personal letters to the exlitor and compiler from gentlemen sport $\times m e n$ living and honting on the grommls named. Care has heren taken to make these reports accurate and whereser the shooting is gond, hat or indiflerent, the faets are plainly stated. Cost of livery, hotels, ete., are given. Handisomely bound in cloth and gold. Price $\$ 1.00$.

\section{THE FISHES OF THE EAST ATLANTIC COAST.}

A practical book on the salt water fishes of the Atlantic Coast, giving the scientifie and popular descriptions, habit, habitat, when, where and how to eateh them, of forty-two fishes that are caught with hok and line: twenty-eight engravings drawn from nature. Handsomely bound in eloth. Price $\$ 1.50$, postage free.

\section{THE ANGLERS' SCORE BOOK.}

Contans blank forms (with stuh) for registry of fish eaught; their species, size, weight, baits used, waters tished in, with contitions of wind, water and weather. Pocket size, paper cover, 1ue; limp cloth, 25e.

\section{THE GAME FISH OF THE WEST.}

A practical Angling Treatise, finlly illustrated. The essays lave been written by the most prominent angling aluthors in Inorica, aud this edition is essentially a text book for anglers and lovers of natural history. Paper. Price 15 cents, postage free.

\section{THE TROUT AND THE BLACK BASS.}

A valuable treatise on these popular game fishes, written by several of the most prominent writers on angling. Fully illustrated. Paper. Price 25 cents, postage free.

Send for Specimen Copy of "American Angler" and Catalogue of Angling Literature. 
Books,

Pamphlets,

Catalogues,

Circulars,

Bill Heads,

Statements,

Checks,

Receipts,

Cards,

News Papers,

etc., etc.

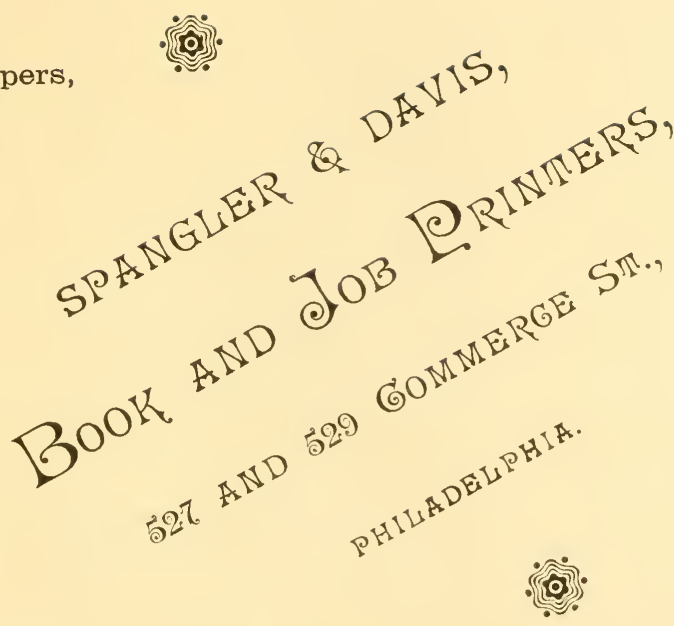

ESTIMATES FURNISHED FOR WORK OF ALL KINDS AT THE SHORTEST NOTICE.

Book and Job Printing of every description, executed promptly, in the best manner and at moderate rates. 


\section{EIEVEN IIUNDIRED}

Students in attendance last year at

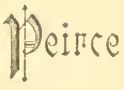

COLLEGE is a

College that "vaunteth not itself." What it is has not been made by any artificial means. It has grown solely by virtue of it: experienced statt of instructors, chosell for their fitness and adaptation to the positions which they fill, by itswonderfully practical and realistic courses of in struction, by its unrivalled light ing, heating. ventilating, and other appointments, great and small, in the far famed "Record Building," whirh proteet the health and promote the convenience of its patrous, and hy the firlelity to the interests of its students of each offices and memher of the Faculty and ear h attachè, from Principal to Janitor.
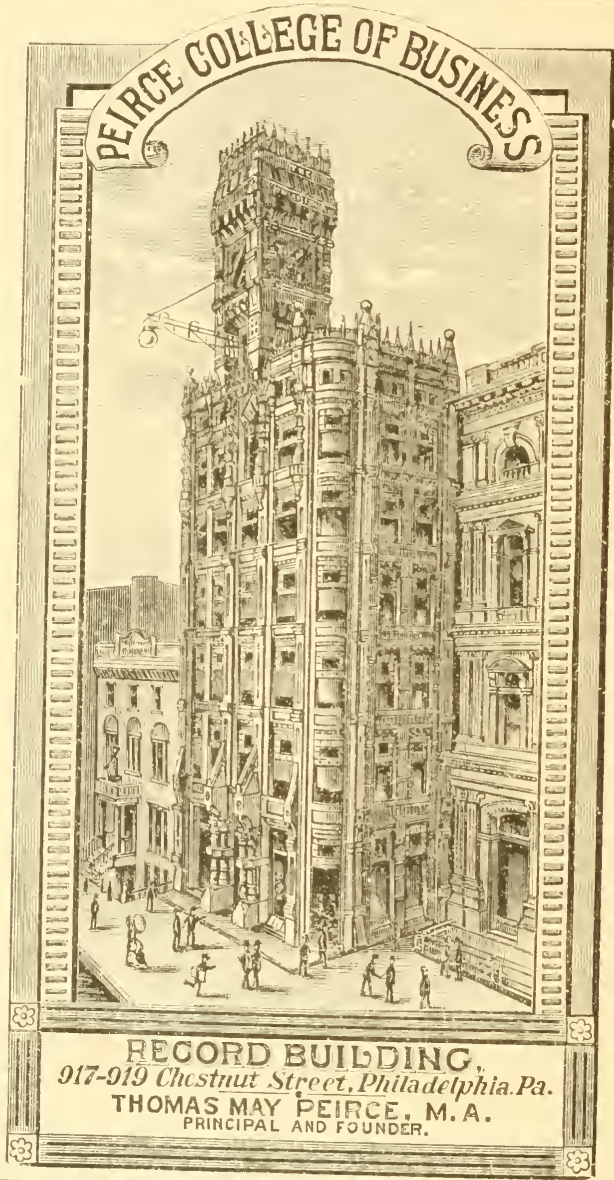
iP HE following from a BISTORY OF PHILADELPEIA, just published.

"This institution has been exceptionally fortunate in the sucress of the students who have sraduated therefrom

It is no marvel that the Peirce College of Business Diploma carries a warranty of efficiency that makes its graduates eagerly sought after by the leading business men of this and other eities."

It is doubtful if very many $P$ hiladelphians even know the extent and importance of its elientage and the results of its training, ontsicle of the facts that inay be gleaned from the roll of sturlents aunually published.

\section{MORNING, AFTERNOON AND NIGHT SESSIONS.}

Send and get one of its Ammal Announcements and a copy of its Commencement Proceedinys, containing Arldresses of Ex-Governor Pattison, Rev. Russell H. Conwell and Robert J. Burdette, that you may be introduced to it, and establish a speaking acquaintance with it if you do 

H.1 18284 





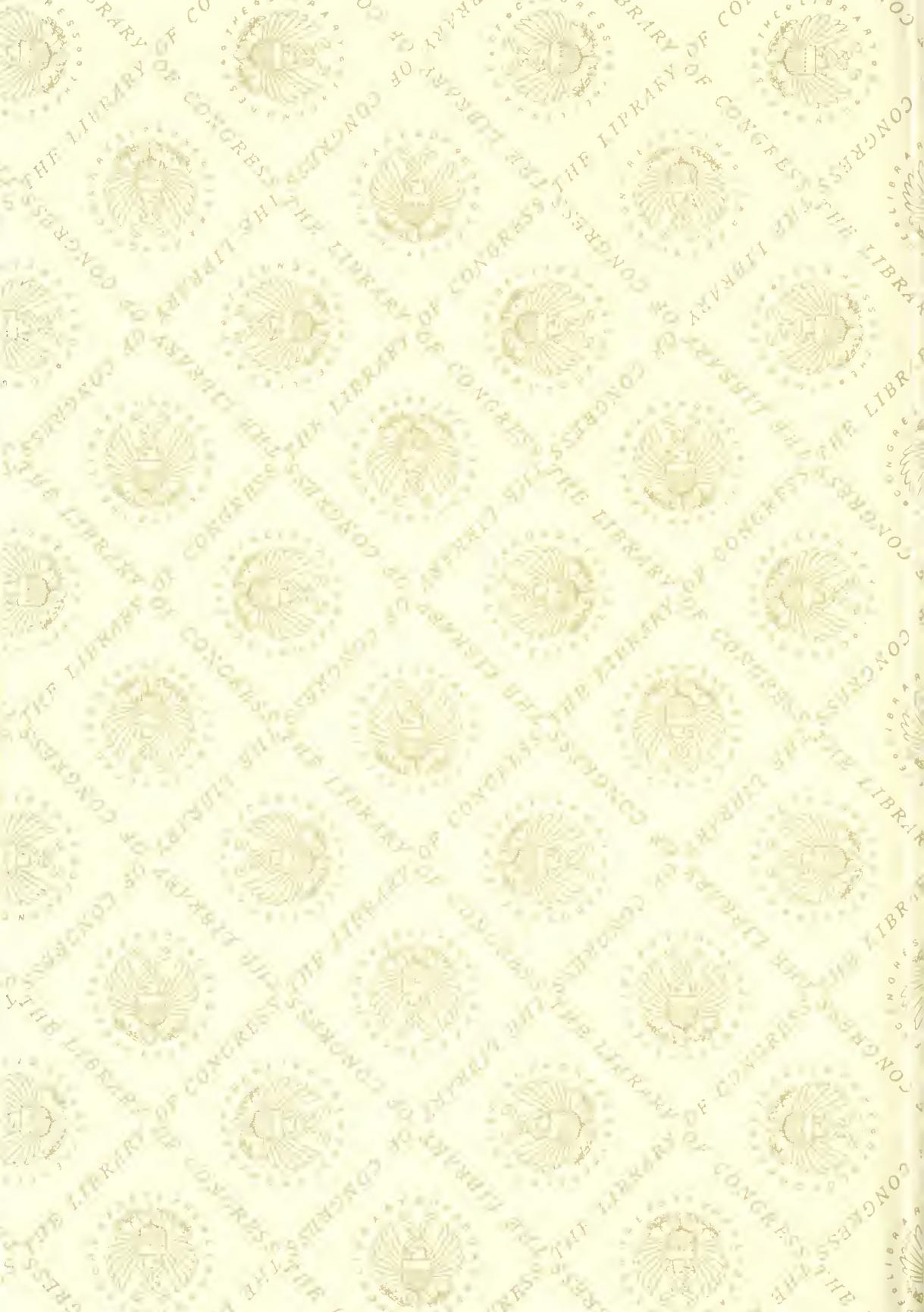




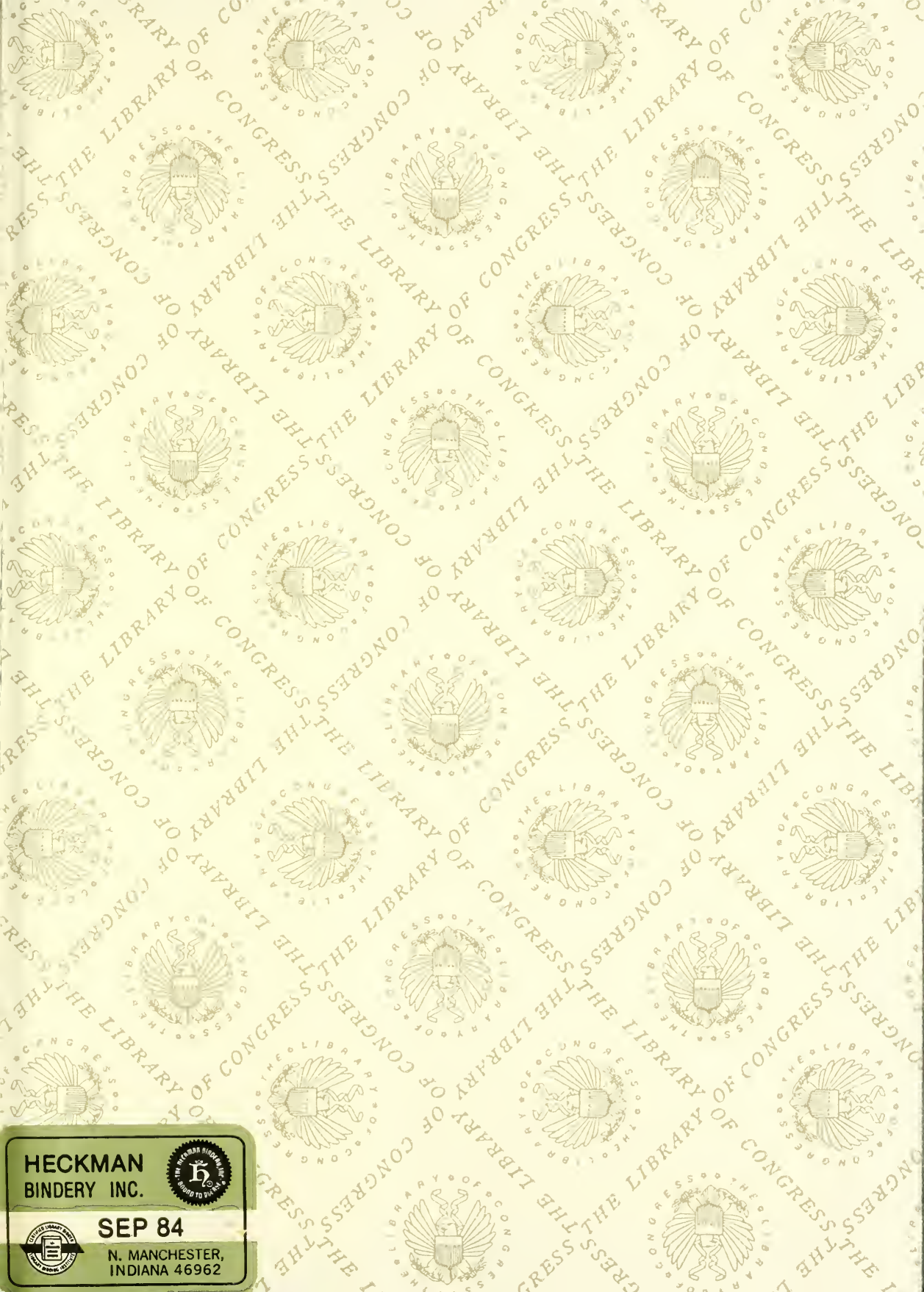




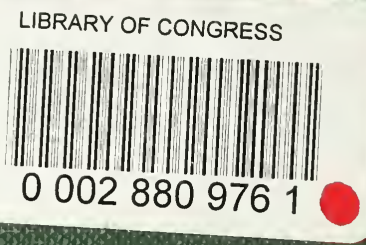

